\title{
Mapping the Relationship among Political Ideology, CSR Mindset and CSR Strategy: A Contingency Perspective Applied to Chinese Managers
}

\author{
Fuming Jiang*, School of Management, Curtin University, Australia \\ Tatiana Zalan, School of Business Administration, American University in Dubai, EAU \\ Herman Tse, Monash Business School, Monash University, Australia \\ Jie Shen, Shenzhen International Business School, Shenzhen University, China
}

\begin{abstract}
The literature on antecedents of corporate social responsibility (CSR) strategies of firms has been predominately content driven. Informed by the managerial sense-making process perspective, we develop a contingency theoretical framework explaining how political ideology of managers affects the choice of CSR strategy for their firms through their CSR mindset. We also explain to what extent the outcome of this process is shaped by the firm's internal institutional arrangements and external factors impacting on the firm. We develop and test several hypotheses using data collected from 129 Chinese managers. The results show that managers with a stronger socialist ideology are likely to develop a mindset favouring CSR, which induces the adoption of a proactive CSR strategy. The CSR mindset mediates the link between socialist ideology and CSR strategy. The strength of the relationship between the CSR mindset and the choice of CSR strategy is moderated by customer response to CSR, industry competition, the role of government, and CSR-related managerial incentives.
\end{abstract}

Keywords Socialist ideology $\cdot$ CSR mindset $\cdot$ CSR strategy $\cdot$ Customer response $\cdot$ Industry competition $\cdot$ Role of government $\cdot$ CSR-related managerial incentives

*Correspondence author: fumingjiang@curtin.edu.au 


\section{Introduction}

Prior studies (Chin et al. 2013; Matten et al. 2003; Murtha and Lenway 1994; Roe 2003; Walters 1977) establish that political ideologies of managers have considerable influence on their firms' strategic responses to corporate social responsibility (CSR). Political ideology is generally conceptualised as a "set of beliefs about the proper order of society and how it can be achieved" (Erikson et al. 1988: 64) and, to emphasise the social nature of ideologies, as "the shared framework of mental models that groups of individuals possess that provide both an interpretation of the environment and a prescription as to how that environment should be structured" (Parsons 1951: 24). Political ideology often constitutes "a more or less central sphere in the broader belief system" and, as a psychological reality, refers "to the content of a belief system which has its origins in postulates or doctrines and gains by its system's characteristics a new and enhanced potential to influence human behaviour in the political and social domains" (Szalay and Kelly 1982: 586). Managers with a left-wing political ideology, especially socialist ideology which is believed to promote CSR (Friedman 1970; Matten et al. 2003), are more likely to support the stakeholder view of the firm advocating business' social responsibilities, while those with a right-wing political ideology, especially capitalist ideology, are more likely to support a shareholder view of the firm upholding economic freedom (Tetlock 2000). However, how and when a political ideology, and in particular socialist ideology, influences managerial thinking and firm's responses to CSR, remains poorly understood, even though these issues are of great theoretical and practical interest to academics, managers and the society at large.

Accordingly, the primary objective of the paper is to explain how a firm's CSR strategy is affected by political ideology and cognition of managers. As pointed out by Basu and Palazzo (2008), prior research on CSR has been predominately content driven and heavily reliant on secondary data (e.g., company annual reports), which can be misleading, because what companies report may not be what they actually do. Moreover, the content driven approach neglects the importance of a firm's internal institutional dynamics and interactions at both the organisational and managerial levels in decision making, especially the cognitive side of the managerial decision making process. Because managerial cognition is consequential in explaining the characteristics of the CSR process as well as the quality of its outcomes, CSR should be studied both as an organisational process and as an individual behaviour (Zollo et al. 2009). Thus, in line with the logic of the cognitive sense-making process approach advocated by Basu and Palazzo (2008) to study CSR behaviour of firms, we develop and test a contingency framework that explains and empirically examines how managers' political ideology affects their CSR decisions in the context of indigenous firms operating in China. We propose that CSR mindset mediates the relationship between political ideologies of managers and CSR strategies of firms. External factors and internal CSR-related institutional arrangements interact with the managers' CSR mindset, which ultimately influences their choice of CSR strategies. The sense-making process focuses on a decision-maker's perception, as well as thinking and understanding of the environmental demands and firm's relationships with the stakeholders, leading to a particular type of firm behaviour (Weick 1995). Therefore, the sense-making approach with a focus on what managers perceive or think of the environment may provide a more reliable basis for inferring the nature of likely CSR outcomes (see Basu and Palazzo 2008: 124). 
We chose China as our empirical context, as it allows us to examine in some depth how managers' political ideologies, and particularly socialist ideologies, impact firms' CSR practices. Since the announcement of the economic reform in 1978, China has undergone a fundamental transformation from a centrally planned socialist economy to what is termed a socialism-oriented market system, yet this transition has not been accompanied by concomitant changes in China's political system (Ip 2009). The Chinese government under the leadership of the Communist Party of China has the political, social and long-term economic motives to encourage business corporations to take on more social responsibilities and has undertaken important initiatives to guide and control overall CSR strategies and practices (Lin 2010). While in theory these government initiatives should have resulted in more advanced CSR practices and better overall CSR performance than in many other countries where capitalism prevails, the reality in modern China is different. Businesses in many industries have been notorious for the establishment of sweatshops and environmental pollution problems, exploitation of labour, substandard products and irresponsible production processes, leading to a tarnished image of CSR, particularly in the recent decade (Ip 2009; Lin 2010). Thus, critical questions persist: firstly, does socialist ideology always promote CSR, as asserted by Friedman (1970)? And secondly, if it does, why does such paradox exist in China? One plausible explanation could be that individuals in transition economies (particularly older adults) have been exposed to ideological justifications for both socialism and capitalism (Jost et al. 2003), resulting in significant heterogeneity in worldviews regarding political, economic and social order (Sidorov et al. 2000). Therefore, we would expect that competing worldviews - or at the very least a spectrum of socialist-oriented ideologies and mindsets with respect to CSR - could coexist in China regardless of the market reforms undertaken.

This study makes two major contributions. Prior academic enquiry into why firms take different stances in response to CSR, as summarised by Basu and Palazzo (2008: 122) and suggested in the earlier section of the paper, has been largely content driven and undertaken predominately from three perspectives. The stakeholder perspective (e.g., Walsh 2005; Le Menestrel et al. 2002) focuses on firms' responses to the stakeholders' expectations and demands; the performance driven perspective (e.g., Porter and Kramer 2006; Wood 1991) largely focuses on the match between the firms' external expectations and the actual CSR stance and activities; and the motivation driven perspective (e.g. Fombrun et al. 2000; Husted 2005; Solomon 1993) examines a firm's extrinsic and/or intrinsic rationales in relation to the firm's responses to CSR. The content driven approach seeks to investigate the "actual" environment situation upon which a firm's choice of CSR strategy is then based, but neglects the cognitive processes of managers, the real decision-makers (Basu and Palazzo 2008). As a result, the seminal work in the Carnegie School tradition (e.g., Simon 1957) and ground-breaking research in behavioural economics (Tversky and Kahneman 1974) notwithstanding, the critical link between managerial cognition (e.g., mindset) and CSR choices and practices has not been adequately addressed in the literature (Agle et al. 1999). This study, with its focus on the cognitive side of managerial decision-making process that concerns the mental models and mindsets of business managers in relation to CSR, will help us to more fully understand and explain how firms respond to societal demands.

Our second contribution is related to the contextualisation of the cognitive side of managerial decision-making process with a specific focus on the moderating effects of a firm's external 
and internal conditions on the relationship between managers' CSR mindset and their strategic responses to CSR. Drawing on Morgan (2007) and Beach and Mitchell (1978), we develop and empirically test a contingency conceptual framework that integrates four distinct perspectives to examine interactive effects of institutional factors (regulatory/government pressures, the regulative institutional pillar; and customer responses, the normative pillar, see Scott 2001), industry factors (i.e., industry competition), and firm factors (i.e., incentive mechanisms) on the CSR mindsets of managers (individual factors), in turn influencing managers' decisions regarding the choice of CSR strategies. This approach is distinct from the conventional main effect models used in prior studies (see Aguinis and Glavas 2012, for a comprehensive review), and is consistent with the call for incorporating multiple perspectives that bear on the social context of CSR decisions (i.e., the individual, organisational, and external social contexts) (Aguilera et al. 2007; Athanasopoulou and Selsky 2015).

The rest of the paper is organised as follows. In the next section, we will define the concepts of political ideology, CSR mindset, and CSR strategies, and subsequently, we develop a contingency theoretical framework and hypotheses depicting how and when socialist political ideology affects choice of CSR strategies. We describe the measurement for each variable, data collection procedures, data analysis and results interpretation in the method section. We then discuss the theoretical contributions and practical implications of the findings. Finally, we acknowledge the shortcomings of this study and suggest potential research ventures for further investigation.

\section{Theoretical Background}

Based on an extensive literature review, in this section we explain the rationale and theoretical underpinnings of the contingency framework integrating macro-, meso- and individual level factors and associated hypotheses. More specifically, we focus on the key variables of the main effect decision-making process linking political ideology of managers, CSR mindset and CSR strategy of firms. We also briefly discuss how the decision-making context that incorporates institution-based conditions, industry-based conditions and firm-based conditions contributes to explaining the process and outcomes of the main effect model. Subsequently, we develop associated hypotheses based on the relevant literature in general and the Chinese context in particular.

\section{Contingency Framework Development}

Synthesis of Theoretical Underpinnings

Although debates regarding the CSR of business are not new (see Friedman 1970; Ullmann 1985), the expectations of citizens and governments of business today have never been higher - companies are expected not only to obey the law but also to solve major economic, environmental, and social problems (Browne and Nuttall 2013). Meanwhile, there is a growing sense that CSR initiatives are not working as well as they should. For instance, Porter and Kramer (2006) note that the prevailing approaches to CSR are so fragmented and disconnected from the business and strategies of firms that they obscure some of the greatest opportunities for firms to benefit society at large. A recent report by McKinsey (Browne and Nuttall 2013) is even more critical of current CSR practices, suggesting that traditional CSR - short-lived, highprofile but relatively inexpensive initiatives and glossy annual reviews of CSR progress - has 
failed to fulfil its core purpose, which is to deeply integrate external engagement into the strategies and operations of firms. Given these complexities in the world of academia and management practice, there is an ever-increasing need to develop sound conceptual underpinnings to explain how firms strategically respond to CSR. Specifically, current literature has not adequately addressed how firms' internal institutional factors - that is, individual managers' mental frames - may influence critical firm decisions such as CSR decisions (see Hoffman and Bazerman 2006), and how the social context of the firm affects the decision making process of managers to reach the decision (Aguilera et al. 2007; Athanasopoulou and Selsky 2015)

We address these concerns by developing and empirically testing a conceptual contingency framework that incorporates multiple dimensions to explain the relationship among political ideology, the CSR mindsets of managers, and strategic responses to CSR. Contingency theory advocates that there is no one best way of organising as firms are open systems that need careful management to satisfy and balance internal needs and to adapt to environmental circumstances, achieving alignment and good fit between the two (Morgan, 2007; Scott, 1981). The contingency theory of managerial decisions suggests that the choice of organisational strategies is dependent upon variables such as the external and internal environment of the organisation and the characteristics (e.g., cognitive attributes) of the decision maker (Beach and Mitchell 1978). In this paper we argue that making decisions on CSR strategies is a process that brings managerial cognition into alignment with the firm's social and organisational environment, especially the expectations of its stakeholders. Specifically, we postulate CSR mindset, an individual-level construct, as the mediation variable that explains how a political ideology affects the choice of a CSR strategy. We argue that institutional, industry-, and firm-level factors are contingencies that interact with the mindsets of individual managers, hence moderating the effect of managerial mindsets on the outcomes of decisions regarding the choice of CSR strategies. This contingency framework incorporates multiple conceptual dimensions enabling us to examine how a firms' external social environment and internal organisational factors interact with managerial cognition to influence the choice of CSR strategy for the firm. It is worth noting that the development of the mindset construct is informed by cognitive theory, which is consistent with the third (i.e., cognitive) pillar in institutional theory. Arguably, this approach may provide us with a deeper understanding of institutional order (Scott 2001).

The CSR mindset, in line with the stakeholder perspective (Donaldson and Preston 1995) and cognitive science research (Thagard 2008), is conceptualised as a multi-dimensional construct (Boal and Peery 1985; Secchi 2009) that encompasses both economic and noneconomic dimensions, which highlights the notion that managers are responsible to multiple constituencies. Ideological commitments are believed to be robust predictors of a wide range of attitudes, preferences, judgements, and behaviours in organisational settings (Jost et al. 2009). Political ideologies become embedded in cognition early in an individual's life and have the capacity, beginning with isolated beliefs, to progressively expand their influence into larger segments of cognitive representations. Initially, ideology begins to determine the content of a person's beliefs, and then it gradually begins to influence the organisation of beliefs, or the very structure of the representational (cognitive) system resisting modification. In general, even more "progressive" and less rigid political ideologies tend to be relatively stable over long periods of time (Szalay and Kelly 1982). Therefore, we believe it is useful to seek the origins 
of CSR mindsets of senior managers in political ideology as well as to investigate the consequences of CSR mindsets for the firms' CSR behaviour (Walters 1977).

Drawing on the political science literature (e.g., Adorno et al. 1950; Jost 2006) and social science literature (e.g., Friedman 1970; Matten, et al. 2003), we consider socialist political ideology, the central focus in our study, as an antecedent to CSR mindset. Jost (2006), following Adorno et al.'s (1950) reasoning, suggested that political ideology affects an individual's cognition (e.g. mindset) and serves an individual's psychological needs (p. 654). Friedman (1970) explicitly connected CSR to the ideology of socialism. Similarly, Matten et al. (2003) contended that socialists are proponents of a stronger responsibility for the corporation in society. Therefore, building on the arguments of Jost (2006) and Adorno et al. (1950), we propose a link between ideology and mindset; while the arguments by Friedman (1970) and Matten et al. (2003) provide a theoretical justification for the link between socialist ideology and CSR mindset. Since a particular ideology can influence a manager's cognitive style and ultimately affect his/her behaviour (Wilson 1995; Tetlock 2000), an explicit connection can be made between a manager's CSR mindset and the firm's strategic response to CSR - which we categorise as reactive, defensive, accommodative, and proactive (Carroll 1979; Ullman 1985; Peng 2009). The general proposition is that managers will adhere to a particular ideology that will motivate them to strategically respond to CSR via their distributed cognitive systems embodying pro-social tendencies (Michel 2007; Jost and Amodio 2012).

Managers are uniquely positioned at the centre of all stakeholder relationships (Peng 2009), hence it is important to understand how the decision making context external to decision makers influences or moderates their decision-making process. Drawing on the comprehensive tripod model of CSR advanced by Peng (2009), we propose that managers' responses to CSR which translate into CSR strategies are moderated by institution-based conditions (role of government), industry-based conditions (industry competition and customer response to CSR) and firm-based conditions (CSR-related managerial incentives). The logic and rationale of this conceptual thinking are depicted in Fig.1.

Insert Fig. 1 about here

\section{Theoretical Framework}

The theoretical arguments presented above have informed our research model in Fig. 2. Consistent with the general tendency to group the predictors of CSR actions and policies into reactive (the reasons that firms must engage in CSR, largely unwillingly) and proactive (the reasons that firms choose to engage in CSR, largely willingly) (Aguinis and Glavas 2012:951; also Ullmann 1985), we structure our arguments around the two extremes of the continuum of strategic responses to CSR - the reactive approach and the proactive approach. Our model predicts that the relationship between a manager's CSR mindset and a firm's strategic response to CSR is contingent on the level of customer responses to CSR, industry competition, role of government, and CSR-related managerial incentives. An individual's current mindset guides the collection and interpretation of new information. Because the mindset acts as an information 
filter, is dynamic and constantly evolves in response to new information, if the latter is consistent with the individual's current mindset, it will reinforce the mindset. Over time, new information appears that is both novel and inconsistent with the individual's current mindset, which may then prompt the individual to change his or her current mindset (Walsh and Charalambides 1990). The moderating variables in our framework are well-established stakeholder variables or their derivatives (e.g., Ullmann 1985; Donaldson and Preston 1995; Henriques and Sadorsky 1999). Stakeholders influence organisations either by exerting direct pressure or by conveying information (Savage et al. 1991; Sharma and Vredenburg 1998; Murillo-Luna et al. 2008), which subsequently alters the mindset of managers, who then process the information conveyed by stakeholders as inputs into organisational decisions. We believe that examining the interactive effects of institutional-, industry-, and firm-level variables with the mindsets of individual managers influencing their CSR decisions is promising, because it is likely to enhance our understanding of the organisational reality of CSR while also enabling researchers to escape conceptual silos (Athanasopoulou and Selsky 2015).

Insert Fig. 2 about here

Hypothesis Development

Political Ideology

From the premise that political ideologies represent socially shared but competing philosophies of life, it is reasonable to expect that different ideologies should elicit and express somewhat different social, cognitive, and motivational styles/tendencies on the part of their adherents (Jost 2006; Jost et al. 2009). Socialist ideology is one of the many varieties of political ideologies. The Chinese socialist ideology emanated from Karl Marx (Jen 1970). Marx (1844/1969), an ardent critic of the capitalist system, asserted that because of private ownership of the means of production, material gain and financial incentives become the paramount economic goals, dominating values and social behaviour. Marx advocated a socialist society that involves abolition of private property and of alienation of workers through human emancipation and the actualisation of personal potential (Fromm 1963).

Mao Zedong, the first generation leader of the People's Republic of China, played a critical role in contextualising the orthodox Marxist principles for the Chinese reality and developed a new form of Marxism known as "The Mao Zedong Thought", commonly termed "Maoism". Maoism espoused a profound faith that human will and spirit were primary determinants of social change. Essentially, there are no substantive differences between the orthodoxies of Marxism and Maoism, even though Maoism further promoted socialist ideology with a particular emphasis on the power of spiritual motivation for the socialist society as a whole (Yang and Stening 2013, 424-425). Drawing on the principles of Marxism and Maoism, the orthodox Chinese socialist ideology can be conceived as a political ideology based on a set of beliefs or doctrines that advocates socialism as a social and economic system characterised by social ownership of the means of production and co-operative management of the economy for the purpose of serving the needs of the entire society. 
Mao Zedong's successor Deng Xiaoping re-evaluated Mao's basic ideological assumptions, including the principles of socialism, and stressed the importance of comprehensively understanding Marxism. He argued that while the essence of Marxism was universal, its concrete applications should be subject to environmental conditions. Thus, in 1978 an era of economic reform was initiated, and a new, much more pragmatic form of socialism, commonly referred to as "Post-Maoism", emerged. Among other things, the re-vamped Chinese socialist ideology encouraged values which were fundamentally materialistic and pragmatic, while the original principles of Marxism remained (Yang and Stening 2012: 444). Thus, Chinese socialist ideology has evolved from being dominated by Marxism to Maoism and subsequently PostMaoism. The country's social and economic systems progressed accordingly from a socialist planned economy to a "socialism-oriented market system", combining features of a communist political system and an economic system that is now, arguably, much closer to capitalism (Huang 2008; Redding and Witt 2007). However, the change in economic doctrine did not trigger a fundamental ideological shift from socialism to capitalism; rather, in the absence of political reform, vestiges of Maoism and the spirit of socialism still prevail (Yang and Stening 2012). Any visible changes in political ideology seem to be confined to variations within the orthodox Chinese socialist ideology (Bjørnskov and Paldam 2012). This study will enable us to empirically examine the effects of such variations in socialist ideology on managers' CSR decisions.

It is also worth noting that, in recent years, while China's economic management policies under the leadership of the new government have become even more focused on free market economy principles, the practice of free market system continues to diverge significantly from those in developed western countries. The Chinese government retains high degree of control of the nation's economic and human assets. Given that the Chinese government has always been directed by the Communist Party of China, the influence of socialist ideology on the country's economic activities remains pervasive, hence the influence of western-style capitalist system, as long as the Party remains in power, will be limited (Chow 2015). According to a recent study, the central communist government is the key driver in CSR development in China, with the state-owned enterprises taking the leading role in implementing CSR in their business activities in response to the government's call for a harmonious socialism with unique Chinese characteristics (CSR ASIA 2015). Culturally, the Confucian principles, including loyalty, honour, and social harmony, are still seen as guiding many of China's business relations (Roper and $\mathrm{Hu}, 2005$; Zhang, 1999). Therefore, while the strength of socialist ideology may wane over time, a significant ideological shift from socialism to capitalism is unlikely to happen any time soon.

\section{CSR Mindset}

A mindset - variously termed a cognitive structure, cognitive filter, mental model and cognitive framework - can be thought of as an abstract model consisting of conceptual structures for representing the knowledge and sets of processes that operate on those structures (Aitkenhead and Slack 1985). An individual's mindset affects the process of attention (i.e., information acquisition) by focusing the individual's attention on selective aspects of the environment, interpretation and sense making (i.e., information perception, interpretation, assimilation, and 
comprehension), and decision making and action (i.e., strategic behaviour) (Daft and Weick 1984).

The cognitive side of CSR, or CSR mindsets of managers, is not well understood, possibly because the notion of "corporate social responsibility" has rarely been considered at an individual level (Secchi 2009), despite early calls to examine both managerial attitudes and organisational behaviours to obtain a more comprehensive understanding of CSR (Zenisek 1979). In some instances, the cognitive structure of CSR is conceptualised as a unidimensional construct (Waddock and Graves 1997; Hemingway and Maclagan 2004) and is explicitly linked to managerial values. In one of the earliest conceptualisations of CSR, a study by Hay and Gray (1974), managerial patterns of behaviours towards CSR are characterised by different sets of values and are divided into three typologies: the profit-maximising manager, the trusteeship manager, and the quality of life manager. These three typologies, Hay and Gray (1974) argued, reflect the evolution of the concept of CSR, and a growing number of business managers, corporations, and academics appear to have progressed to the quality of life concept (e.g., focusing on employee rights, social justice, and the preservation of the environment). However, it is more plausible to conceptualise CSR mindset from a multi-dimensional perspective, which is consistent with the main premises of stakeholder theory (Donaldson and Preston 1995). Boal and Peery (1985) empirically verified three conceptually distinct cognitive dimensions of CSR: (1) economic/market values vs. non-economic/human values, which was the most important dimension; (2) ethics (non-maleficence vs. beneficence); and (3) consequences for relevant interest groups. The multidimensionality of attitudes towards CSR has been further confirmed in a study of the values of top management in 15 countries (Waldman et al. 2006), in that managers appear to identify with three CSR dimensions: (1) shareholder/owner (as in the classic economic theory of profit maximisation), (2) broader stakeholder relations (responsibilities to identifiable, non-financial stakeholders, such as employees or consumer groups), and (3) community/state welfare (values relevant to a larger societal entity beyond immediate stakeholder groups).

Consistent with this body of work, and particularly the stakeholder perspective in CSR research (Donaldson and Preston 1995) as well as research in cognitive science (Thagard 2008), we conceptualise CSR mindset as a multi-dimensional construct (Secchi 2009), encompassing both economic and non-economic dimensions. An extensive body of conceptual and empirical literature explains why managerial values and attitudes towards CSR are likely to have a strong influence on organisational-level outcomes (Williams and Aguilera 2008). The content of managerial CSR mindset can be influenced by an individual manager's distinctive system of core beliefs and values (Schein, 1984), as well as by more specific beliefs and values relating to particular domains (Hay and Gray 1974), such as CSR. Hence, the substantive content of each individual manager's CSR mindset (i.e., what information and knowledge are processed and stored) can be very different because of substantial variation among individuals and across cultures (Steinbruner 1974; Walsh 1995); by contrast, the structure of CSR mindset (i.e., how beliefs and values are organised) is far more universal (Steinbruner, 1974). In line with the logic of cognitive theory (see Steinbruner 1974, Ch. 4), individual manager's CSR mindsets tend to be internally consistent and coherent, and difficult to change without significant cognitive restructuring, either of the individual's beliefs or of 'reality' (Bartunek 1984). 


\section{CSR Strategies}

CSR strategies refer to the options a firm can choose from in response to the demands and/or expectations of the society in relation to CSR. A well accepted classification of responses includes four CSR strategies; namely reaction, defence, accommodation, and pro-action (Carroll, 1979; Henriques and Sadorsky 1999; Wartick and Cochran 1985; also Peng 2009). This categorisation has been subsequently recast by other researchers in the light of resource dependence theory and institutional theory to emphasise conformity to the expectations of institutions and stakeholders (e.g., Hoffman 1999). According to this body of work, a reactive strategy is passive, and denial is typically the first line of defence. The need to take necessary action is not internalised through cognitive beliefs and is not becoming the norm in practice; thus, only formal regulatory pressures can compel managers to act (Peng 2009). A defensive strategy focuses on regulatory compliance; in the absence of regulatory pressures, firms often fight informal pressures from the media, activists and customer groups (Peng, 2009). An accommodative strategy features emerging organisational norms to accept responsibility and a set of increasingly internalised cognitive beliefs and values towards making certain changes (Peng 2009). Proactive firms and their managers anticipate institutional changes, often becoming prime agents of change and establishing industry norms. Examples of Chinese firms pursuing these four strategies are presented in Table 1.

Insert Table 1 about here

These various strategic responses to CSR, in accordance with our conceptual framework, can ultimately be traced to how strongly managers believe in socialist ideology. Although many political ideologies may coexist in the same national context, for a society to be cohesive and avoid polarisation, a dominant view tends to be held by the majority of individuals (Leach 1993). Such a dominant view, the key factor in defining a political ideology, concerns the extent to which governments and public policy should regulate markets and economic affairs (Walters 1977), particularly with respect to property rights, the rule of law, anti-trust legislation, financial systems, and the competitive behaviours of businesses (Stiglitz 1992). Communism (and its variants) promotes collectivism, class struggle, anti-capitalism, dictatorship of the proletariat, and active involvement of the state in civil rights provision (e.g., health care, education, vacations, and cultural goods and services) (Ip 2009). Although the economic system has undergone transitions, as we have discussed previously, at least some senior executives in China (and certainly those who were socialised under the old regime) will, because of the mindset's internal consistency principle, continue to be ideologically predisposed to socialism.

Based on the discussion above, we argue that managers with a stronger belief in socialist ideology will develop a more socialist-oriented CSR mindset, which is likely to induce managers to adopt proactive CSR strategies. Consistent with these arguments, we advance the following hypotheses: 
Hypothesis 1a Socialist ideology will be positively associated with managers' CSR mindset valuing non-economic responsibilities (i.e., a socialist-oriented CSR mindset).

Hypothesis 1b Managers with a socialist-oriented CSR mindset will adopt a proactive CSR strategy for their firms.

Following our earlier discussions and arguments supporting Hypotheses $1 \mathrm{a}$ and $1 \mathrm{~b}$ and the hypothesised relationships specified in our conceptual framework (Fig. 2), we predict that socialist ideology is indirectly and positively associated with the proactiveness of CSR strategy via managers' socialist-oriented CSR mindset. Consequently,

Hypothesis 1c The CSR mindset of managers mediates the relationship between socialist ideology and the choice of CSR strategy.

\section{Contingency Factors}

We argue that the relationship between CSR mindsets of senior managers and the strategic responses to CSR discussed previously is moderated by a range of variables. As pointed out in the earlier section of the paper, to ensure simplicity and to account for the notion that strategic responses to CSR can best be conceptualised as a continuum, we focus on the two extremes of the continuum: the reactive approach and the proactive approach. Even if managers as individuals have an inherent predisposition towards a reactive approach to CSR because of their weak socialist mindset, they may be incentivised or pressured into adopting a proactive approach. We propose that the relationship between CSR mindset and the proactiveness of a CSR approach is moderated by the customer responses to CSR, industry competition, the role of government, and CSR-related managerial incentives of firms. Arguably, this overall contingency proposition is particularly relevant in the Chinese context, which is an intriguing paradox of socialist ideology that still dominates the society and is believed to be conducive to CSR, and the socially irresponsible practices of many firms in China.

\section{Customer Responses to CSR}

Rational economic perspective (Kitzmueller 2008) suggests that consumers and their social preferences may translate into demand for CSR and may induce profit-maximising firms and their managers to supply the levels of CSR in accordance with their competitive environment. When consumer demand for CSR (coupled with demand from other stakeholders) is assessed against supply for CSR (via cost-benefit analysis), it is possible to calculate an optimal level of CSR investment that maximises profits but also satisfies stakeholder demand (McWilliams and Siegel 2001). Research informed by stakeholder and institutional theory (e.g., Sturdivant 1979; Handelman and Arnold 1999; Campbell 2007) provides further insight into the likely change in executives' mindsets leading them to adopt an active stance towards CSR. A firm's actions appeal to the multidimensionality of the consumer not only as an economic being but also as a member of a family, community, and country (Handelman and Arnold 1999). A strong record of CSR may directly improve customer satisfaction and loyalty, which in turn affects a firm's market value (Luo and Bhattacharya 2006), lowers the rate of customer churn, and influences the attitudes and buying behaviour of customers more generally (e.g., Sen et al. 2006). Clearly, 
CSR-related initiatives that customers value have important strategic implications (McWilliams et al. 2006) in that they raise customers' willingness to pay for a product or service and thus have an immediate effect on a firm's bottom line.

Leveraging CSR could be particularly salient in a country like China that is arguably still characterised as a socialist society (Lin 2010), in which the majority of consumers' purchasing decisions can be influenced by the social reputation of a brand (Edelman 2010). Chinese consumers have been able to exercise their purchasing power to castigate and pressure firms that are not being socially responsible with regards to environmental protection, product safety, and community investment, and to reward those that are perceived as excelling in these areas (Zadek et al. 2012). Institutional theory predicts that if consumers are engaged in monitoring CSR behaviour of firms, then managers will be more likely to act in socially responsible, proactive ways (Campbell 2007). Therefore, we propose the following hypothesis:

Hypothesis 2 Customer responses to the CSR strategy of firms positively moderate the relationship between the CSR mindset of managers and the choice of CSR strategy.

\section{Industry Competition}

A second contingency is the level of industry competition which influences the development of the firm's strategic response to CSR (Aragón-Correa and Sharma 2003). It has been shown that managers interpret CSR issues as either threats or opportunities (Sharma 2000). Although CSR is generally viewed as an opportunity to create sustainable competitive advantages for firms (Porter and Kramer 2006), hence encouraging managers to take a proactive stance, the intensity of industry competition, which is understood here broadly (as in Porter 2008), may moderate these attitudes. From a theoretical perspective, if the pressure from competitive forces (e.g., suppliers of labour and capital or buyers) is high, then the industry's intrinsic profitability will be low, which may negatively influence an individual firm's competitive position and therefore its performance (see Porter 2008).

Firms that participate in CSR activities because of competitive pressures must raise prices, reduce wages, accept smaller profits, pay smaller dividends, and eventually accept economic consequences, such as a loss of market share and reputation, shareholder litigation, corporate takeover, or even closure (Reinhardt et al. 2008). The industry effect is also consequential: in low-growth industries populated by mature firms selling standardised products and characterised by intense competition, the adoption of a proactive stance to CSR would be difficult, requiring a significant change in organisational structures and norms (Russo and Fouts 1997). If competitive pressures are high, then managers will filter their responsibilities through an economic lens (Elhauge 2005; Friedman 1970), and will be unlikely to take any action beyond the minimal level of regulatory compliance. As a result, we may expect that executives with a socialist CSR mindset will steer their firms to adopt a less proactive, if not reactive, strategic posture.

The argument regarding the moderating effect of competition is particularly valid in our research setting, where the old view of China as a market characterised by a low level of competition is no longer valid (Jiang and Stening 2013; Luo 2007): competition is intense among aggressive local firms and between local firms and multinationals. Regulatory measures, 
coupled with increased competition from imports as substitutes, have had the effect of significantly lowering entry barriers and have eventually intensified local rivalry. Under conditions of intense competition, the primary responsibility of managers would be to devote more of their attention and firm resources to crafting a defensible position to prevent the erosion of competitive advantages and/or monopoly/oligopoly power (Russo and Fouts 1997). Thus, it is plausible that managers with a socialist CSR mindset will nevertheless adopt a less proactive, or even a reactive stance to CSR.

Hypothesis 3 Industry competition negatively moderates the relationship between the CSR mindset of managers and the choice of CSR strategy.

\section{Role of Government}

Managers and their firms are embedded in a social milieu that affects their economic behaviour (Granovetter 1985: 487). From the perspective of institutional theory, pressures for a firm to adopt specific policies emerge from several sources, including coercion from the state (Fligstein 1991) and other stakeholders (from trade associations, informal networks, leading firms, and local public agencies, among others) (Murillo-Luna et al. 2008). Thus, DiMaggio and Powell (1983) identified several mechanisms that encourage conformity among organisations: normative isomorphism (endorsement of particular practices by key or influential actors in the field), coercive isomorphism (compliance with official and unofficial rules resulting from expectations of reward or punishment for non-compliance), and mimetic isomorphism (imitation based on widespread adoption and the resulting taken-for-granted character of particular practices).

Further theorising and research (e.g., Campbell 2007; Scott, 2001) has confirmed the important role of institutional influences in organisational practices, with specific applications in the CSR area (Besser and Miller 2011). For example, Fox et al. (2002) propose new public sector roles by governments to enable an environment for CSR: mandatory (legislative), facilitating (guidelines on content), partnering (engagement with multiple stakeholders), and endorsing (publicity). More recently, a relational state perspective - a perspective that argues for a transformed role and responsibilities of social agents, above all in government and public sectors - has become influential (see Midttun, 2005). Drawing on the relational state thesis, Albareda, Ysa and Lozano (2005) develop a comprehensive policy making and enforcement framework which analyses relations among the various social agents and actors including government, businesses and civil society. The more co-operation and synergies in the areas of intersection between the sectors can be achieved, the greater the possibility of success in implementing CSR and overcoming the limitations presented by each sector acting on its own.

The concept of CSR is relatively new to China, and there was no mention of CSR in the first Chinese Company Law that was drafted in the 1990s. The awareness of CSR only started in the 1990s when unethical business practices were rampant, leading the government to eventually enshrine CSR in legislation (Jensen 2006; Zhao, 2014). After a spate of corporate scandals and CSR-related incidents such as food poisoning, unfair treatment of employees, and negligence of the environment (Ip 2009), government intervention at various levels increased, and 
measures for increased accountability of businesses and for sustainable development of industries started to take effect. Continuous government efforts in promoting CSR behaviour reinforce the importance of CSR initiatives, helping to develop and enhance the CSR consciousness of managers. Partly as a result of these initiatives, a large majority of Chinese business leaders have strong positive attitudes toward CSR, as revealed in recent surveys (Ip 2009). It is plausible that, influenced by government initiatives which either promote or enforce CSR, managers would be inclined to develop and strengthen their CSR mindset. Based on these arguments, we propose the following hypothesis:

Hypothesis 4 The role of government positively moderates the relationship between the CSR mindset of managers and the choice of CSR strategy.

\section{Managerial Incentives}

Much of the CSR literature addressing executive compensation has traditionally explained the most effective mechanisms for shaping managerial behaviour with reference to agency theory, often in conjunction with stakeholder or institutional theory (e.g., Mahoney and Thorn 2006; Berrone and Gomez-Mejia 2009; Cai et al. 2011). Agency theory (e.g. Eisenhardt 1989; Jensen 2002) predicts that compensation policy will be designed to give the executive (the agent) incentives to select and implement actions that increase the wealth of shareholders (the principal). Because CSR investments are uncertain and unlikely to result in enhanced shortterm profit (Hart 1995; Berrone and Gomez-Mejia 2009), it has been argued that a short-term focus on executive pay (e.g., salaries and bonuses) may not lead to increased CSR performance. By contrast, a long-term executive pay structure may encourage executives to engage in CSR more proactively (Berrone and Gomez-Meija 2009; Deckop et al. 2006), because CSR-related reputational effects can take a few years to realise (Short 2004). However, critics warn that an incentive approach to human motivation may indeed encourage managers to conclude that purely selfish behaviour is expected; meanwhile, the possibility of reaping large personal rewards may tempt executives to cut corners ethically and legally (Lie 2005; Stout 2012). Consequently, long-term compensation components are still not sufficient to adequately address the classical agency problems of moral hazard (unobserved actions by an agent that may be damaging to a principal's interest) and adverse selection (hidden information) (Berrone and Gomez-Meija 2009) with respect to rewarding behaviours that promote CSR.

Even though the importance of material incentives in shaping managers' mindsets, attitudes and behaviours toward CSR is evident, it may have a rather limited effect in the Chinese context, as managerial incentive schemes can be ill-equipped to encourage Chinese managers to take a proactive stance in relation to CSR initiatives. We argue that managers with a socialist mindset will be dis-incentivised by material, high-powered reward schemes. Consistent with the hypothesis that firms could use CSR to resolve conflicts between managers and other stakeholders (Cai et al. 2011), executives in socially responsible firms are likely to accept more modest pay (compared with the executives of socially irresponsible firms) (Potts 2006; Stout 2012). In these firms, compensation systems may be important signals of the values, morals, and virtues underlying the operations of an organisation (Bloom 2004), reflecting those of 
firms' executives. When values are shared by people in the same cultural community, they become cultural values (Schwartz 1994).

Spirituality and group orientation are two important dimensions of the Chinese cultural values. Spirituality was used under the Confucian principles as the ultimate standard by which to measure personal dignity. Good relations with others, or a group orientation, as well as "developing the internal moral self" and "conquering selfishness" (Yu 1996: 233). were also promoted by Confucianism as a source of happiness and social stability. It is logical to posit that the Chinese will place less value on monetary incentives (Yau 1994; Zheng 1997). However, cultural values are not the only factors shaping materialistic tendencies (Richins and Rudmin 1994), political factors must also be taken into account. Maoism emphasised egalitarianism and considered material affluence to be the stigma of capitalism and anathema to the values of the new China (Yang and Stening 2012: 443). Even though China has undergone dramatic economic and social change, the values and norms embedded in and derived from spiritualism, collectivism, Confucianism and socialism are still the fundamental forces shaping people's thinking and beliefs (Yang and Stening 2013). In summary, we could expect a negative moderating effect of managerial incentives on the relationship between CSR mindset and CSR strategy. Therefore, we propose the following hypothesis:

Hypothesis 5 CSR-related managerial incentives will negatively moderate the relationship between the CSR mindset of managers and the choice of CSR strategy.

\section{Method}

\section{Measurement}

Except for the dependent variable construct (CSR strategy), the other variables, including the independent variable or antecedent (socialist ideology), the mediator (socialist CSR mindset), and four moderators (customer response to CSR, industry competition, the role of government, and managerial incentives) used a rating scale ranging from 1 for "strongly disagree" to 10 for "strongly agree." Based on our experience, Chinese respondents tend to be uncomfortable with five- or seven-point scales, and 10-point scales are more appropriate for perception-based measurement or assessment. The questionnaire was reviewed by two senior marketing academic researchers at Donghua University in Shanghai. One has a specific research interest in CSR of Chinese firms, and the other has a specific research interest in branding. Subsequently, the questionnaire was revised based on the feedback provided by the two academic researchers before data collection was conducted.

\section{CSR Strategy}

We adopted four dimensions, including "a firm's overall responses to CSR," "managerial commitment to CSR," "actual CSR practices in place," and "CSR reporting," using Wartick and Cochran's (1985) and Carroll's (1979) categorisation, ranging from the lowest to the highest level of commitment, coded as " 1 " for reactive, " 2 " for defensive, " 3 " for accommodative, and "4" for proactive. For each dimension, we adopted the four statements developed by Henriques and Sadorsky (1999) representing the four levels of commitment from "1" being the lowest to " 4 " being the highest, respectively. 


\section{Socialist Ideology}

In order to measure the strength of socialist ideology of managers, we adopted four statements from the survey study by Jost et al. (2003) conducted in Hungary, a former socialist country whose economic system has been in transition from a centrally planned to a more market oriented economic system. Thus, the items generated from Jost et al.'s (2003) study are particularly suitable for the Chinese context. We also included five statements drawing on classical works on socialism and capitalism by Marx and Engels (1878/2009) and Lenin (1917). We have identified these additional statements based on our deep understanding of the socialist system and ideology developed as a result of our education and upbringing in China. Political education, with its emphasis on capitalist and socialist ideologies of Marx, Engels, Lenin and Mao Zedong, has always been an important subject built into the curriculum from primary school to university and was also reinforced in organisations. The so-called Socialism Oriented Market Economy is a reflection of such ideological embeddedness in today's China. Ordinary Chinese people usually have a rather good understanding of the meaning of socialist ideology.

We also identified one item from Schweickart et al.'s (1998: 61-63) work that argues that " fundamentally, a socialist society must be one in which the economy is run on the principle of the direct satisfaction of human needs, since a socialist economy is based on the principle of production for use, to directly satisfy economic demand and human needs, and objects are valued by their use-value, as opposed to the principle of production for profit and accumulation of capital". The argument is consistent with the socialist ideology as revealed in Marx and Engels' (1878/2009) and Lenin's (1917) classic works. A one-factor analysis with a varimax rotation was conducted and yielded factor loadings ranging from 0.68 to 0.93 , which is acceptable with rather high loadings. Stevens (1992) suggested using a cut-off of 0.4, irrespective of sample size. According to cut-offs suggested by Comrey and Lee (1992) and Tabachnick and Fidell (2007), factor loading cut-offs going from 0.32 (poor), 0.45 (fair), 0.55 (good), 0.63 (very good) or 0.71 (excellent) are all acceptable. The ten items generated a Cronbach's Alpha coefficient of 0.87 , indicating a rather high scale reliability of the measures. The item statements and respective sources are presented in Appendix A1.

\section{CSR Mindset}

We took eleven statements from Ford and McLaughlin (1984, p.670) representing arguments for CSR which are consistent with the stakeholder perspective (Donaldson and Preston, 1995) and encompass both economic and non-economic dimensions. Of the eleven items, seven items represent the economic dimensions, and the rest of four items represent the non-economic dimension. These statements, which originate in Davis' (1973) seminal article on social responsibility, help to reveal managers' views on the proper role of businesses in society. Consistent with the Ford and McLaughlin's study (1984, p.670), we utilised philosophical statements such as "Responsible corporate behaviour can be in the best economic interest of the stockholders" to represent argument for corporate acceptance of social responsibility. The format of philosophical statement was originally developed and used by Ostlund (1973). The statements indicate the strength of managers' beliefs in advocating corporate acceptance of social responsibility, which lends insight into their commitment and attitudes toward various socially responsible activities (Ford and McLaughlin, 1984, p.669-670). A one factor analysis with a varimax rotation was conducted and generated factor loadings ranging from 0.54 to 0.70 
for most items, with only one item that has a factor loading of 0.35 , which is considered as at an acceptable level (Comrey and Lee, 1992; Tabachnick and Fidell, 2007). The eleven items yielded a Cronbach's Alpha coefficient of 0.85 , indicating a rather high scale reliability of the measures. The item statements and respective sources are presented in Appendix A2.

\section{Customer response to CSR}

Drawing on prior studies, we adapted four items from Maignan (2001) and one item from Luo and Bhattacharya (2006) to measure customer response to CSR. Following a two-step iteration of instrument development, Maignan (2001) developed five items to measure consumers' support of responsible business. These five items were worded using the first person as the respondents were consumers. We reworded the statements and used the third person "customers". We also added one item that was identified based on a finding of Luo and Bhattacharya's (2006) study revealing that firms who are perceived more favourably for their CSR initiatives enjoy greater customer satisfaction. CSR initiatives constitute a key element of corporate identity that can induce customers to develop a sense of connection with the company (Bhattacharya and Sen, 2003), and a company's strong record of CSR provides a favourable condition that positively influences customers' perception of and attitude toward the company (Brown and Dacin, 1997). Following the review of the questionnaire by two senior marketing academic researchers, we reduced the number of items adapted from Maignan (2001) to four items and further reworded the item statements in order to suit the Chinese respondents better. In addition, the five items developed by Maignan (2001) were used in the contexts of France, Germany and the USA, implying that significant adaptation is essential for the Chinese context. The remaining five items used in this study are presented in Appendix A3. A one factor analysis with a varimax rotation was conducted and generated factor loadings for the items ranging from 0.47 to 0.87 , which is at an acceptable level (Comrey and Lee, 1992; Tabachnick and Fidell, 2007). These items yielded a Cronbach's Alpha coefficient of 0.83 , indicating a rather high scale reliability of the measures.

\section{Industry competition}

We adopted six well-established items used in Jaworski and Kohli (1993) to measure the intensity of industry competition. Jaworki and Kohli developed these six items through a 4phase iterative procedure. The authors first independently generated a large pool of items, and then carried out three rounds of pretesting-revising processes. The items were pretested with marketing managers and non-marketing managers including top management levels for the first round, and then academic experts in the marketing discipline in the second round. The final round of pretesting was done with the marketing managers from the survey population. Since the informants for pretesting the items in Jaworski and Kohli's (1993) study are similar to the survey respondents in our study, we consider the items as valid measures for our study. A one factor analysis with a varimax rotation generated factor loadings for the items ranging from 0.54 to 0.84 in our Chinese sample, which is at an acceptable level (Comrey and Lee, 1992; Tabachnick and Fidell, 2007). The six items yielded a Cronbach's Alpha coefficient of 0.81 in Jaworski and Kohi's (1993) study and 0.94 in the Chinese sample for our study. The item statements are presented in Appendix A4. 


\section{Role of government}

We drew on Albareda et al.'s (2005) relational framework enabling a holistic analysis of CSR while taking into account relations among government, business and civil society. Their study uses a large number of items from the perspectives of multiple stakeholders. Our measurement items were also informed by a critical analysis of the existing literature (e.g. Besser and Miller 2011; Fligstein 1991; Fox et al. 2002; Ip 2009; Jensen 2006; Zhao 2014), which helped us to more fully understand the role of government in the Chinese context. Beyond the role of government as a legislative body making CSR policies mandatory, government is also expected to be a promoter of CSR. In line with these two dimensions, we employed four items to measure the role of government as a promoter of CSR infinitives and activities by businesses, and three items to reflect the regulatory role that enforces CSR polices and rules. A one factor analysis with a varimax rotation generated factor loadings for the items ranging from 0.61 to 0.84 , which is at an acceptable level (Comrey and Lee, 1992; Tabachnick and Fidell, 2007). The seven items together yield a Cronbach's Alpha coefficient of 0.91, indicating a rather high level of scale reliability of the measurement items. The item statements and sources for these moderators are presented in Appendix A5. The underpinning dimensions of government role as a regulator (e.g., strengthening government monitoring role for law or policy enforcement) and a promoter (e.g., providing financial and fiscal incentives in government programs to award good CSR behaviours, etc.) is also employed in a recent study conducted by CSR Asia (2015) in the Chinese context. The study shows that the government is the key driver of CSR, both in terms of enforcing legislative measures and positively encouraging CSR.

\section{Managerial incentives}

In prior research, managerial incentives as a predictor of a strong / weak social performance are often measured using objective publicly available data. For example, the CEO ownership stake is measured as a percentage of outstanding shares owned by the CEO as reported by Disclosure, while salary is measured as CEO salary as reported in Execucomp (see Berrone and GomezMeija 2009; McGuire et al. 2003). Given the sensitive nature of our research, we decided against using direct questions such as "What is the percentage of base salary, stock options, bonuses and other components in your total compensation package?" In addition, matching the respondents in our survey with objective data on their salaries and other incentives from databases would not have been feasible. Accordingly, we developed four statements based on the received literature on the role of managerial incentives in firm overall performance, including CSR performance (e.g., Berrone and Gomez-Meija 2009; Deckop et al. 2006; McGuire et al. 2003) and our understanding of the importance of material incentives in the Chinese value system (e.g., Zheng 1997; Yang and Stening 2013). These statements link a manager's individual performance to a company's overall goal (item 1) and a manager's compensation to CSR performance (item 2), and aim to draw out the importance of individual performance on the CSR metric relative to financial metrics (items 3 and 4). A one factor analysis with a varimax rotation generated factor loadings for the items ranging from 0.43 to 0.86, which is at an acceptable level (Comrey and Lee 1992; Tabachnick and Fidell 2007). The four items yielded a Cronbach's Alpha coefficient of 0.77 , indicating good scale reliability of the measurement items. The items are presented in Appendix A6. 


\section{Data Collection}

Two types of questionnaires were developed, one for the general manager and the other for the functional-level manager. We requested that the general manager, one sales and marketing manager, and one production manager from each company participate in the survey. The questionnaires and statements that concern the same issues were worded in a manner that was suitable for the respondents in their respective positions in their companies. The dependent variable constructs, the proactiveness of CSR strategies at the firm and functional departmental levels, were cross-examined by the general manager and functional-level managers. The dependent variables, the reactiveness of CSR strategy or the level of CSR performance of the company and each department, were cross-assessed by both the general manager and functional managers. The questionnaires for the general manager and the two functional-level managers were delivered separately by the research assistant. Each questionnaire was placed in an envelope to ensure that when a respondent had completed the survey, he or she could place the questionnaire back into the sealed envelope. All completed questionnaires (sealed in envelopes) for each company were collected individually by our research assistant and were inserted together into a large envelope for each participating company, and the envelope was then sealed. To ensure confidentiality, this procedure was clearly explained to the participants before they began answering the questionnaires.

We conducted the survey in Chengdu, the capital city of the Sichuan Province of China, in 2012. The survey was endorsed by the Chengdu Municipal Council. A total of 129 managers representing 43 machinery equipment manufacturing companies participated in this study. In each of the 43 companies, three managers (one general manager, one sales and marketing manager, and one production manager) participated in this study. An independent-sample t-test of the mean scores of all variables showed no significant differences between the sub-samples of general and functional managers. Of the 129 participating managers, 56 (43.4\%) of them were members of the Communist Part of China and only 19 (14.7\%) were female. $21(16.3 \%)$ managers had a master's degree; 75 (58.1\%) had a bachelor degree; 30 (23.3\%) completed college diploma programs; and three managers (2.4\%) did not have a tertiary qualification. 67 $(51.9 \%)$ managers were 40 years old or under, and the rest were over 40 years old. Of the participating companies, 34 companies were privately owned; 11 companies were state owned, and four companies had foreign ownership. Of the 34 private companies, 25 companies were $100 \%$ privately owned; 6 companies had joint ownership with the state; one company formed a joint venture with a foreign investor; and the remaining one was a joint venture between the state and a foreign investor. Of the 11 state-owned companies, only one was a wholly owned state company. The four foreign-owned companies had four different forms of ownership structure, including a wholly owned foreign subsidiary, a joint venture with a state company, a joint venture with a private company, and a joint venture with both state and private companies. The participating companies manufactured machinery and equipment for a variety of industry sectors, including food processing, building materials and construction, electronics, and printing and textiles.

\section{Data Analysis}

We employed hierarchical regression analyses to examine our hypotheses and the overall model in two steps. We first tested a simple mediation model (H1a to H1c) and then examined the 
moderated model ( $\mathrm{H} 2$ to $\mathrm{H} 5)$ by integrating the four proposed moderating variables into the relationships between the CSR mindsets of managers and the CSR strategies of firms. Because the data were collected from managers at different levels, we conducted an ANOVA to examine whether the mean scores of all study variables were significantly different from one another. The results showed no significant differences for the seven variables across the functional and general manager samples. The results provided rationale for combining the data collected from the functional and general manager sub-samples for subsequent analyses.

The rationale behind H1a to H1c suggests an indirect effect model in which the effect of the political ideology of managers on the CSR strategy of firms is transmitted via the CSR mindset of managers. Therefore, we tested the mediation hypotheses (H1 to H3) utilising the mediation procedure outlined by Preacher and Hayes (2004) to estimate the indirect effect of the CSR mindsets of managers on the relationship between the political ideology of managers and the CSR strategies of firms. With respect to $\mathrm{H} 2$ to $\mathrm{H} 5$, we expected that customer responses to CSR, industry competition, the role of government, and managerial incentives towards CSR would moderate the positive relationship between the CSR mindsets of managers and the CSR strategies of firms.

Results

Table 2 reports the descriptive statistics, reliabilities, and inter-correlations among the main variables in this study. As predicted, the political ideology of managers was associated with the CSR mindsets of managers, customer responses to CSR, industry competition, the role of government, managerial incentives towards CSR, and the CSR strategies of firms.

Insert Table 2 about here

\section{Mediation Effect}

All results related to Hypothesis 1a to Hypothesis 1c are reported in Table 3. Hypothesis 1a, which predicted that the political ideology of managers would be positively associated with the CSR mindsets of managers, is supported $(\beta=0.36, \mathrm{p}=.000)$. Further, the CSR mindsets of managers were found to significantly and positively influence the CSR strategies of firms $(\beta=$ $0.24, \mathrm{p}=.007)$. Hence, Hypothesis $1 \mathrm{~b}$ is also confirmed. Finally, the CSR mindsets of managers were found to have a marginally significant indirect effect on the CSR strategies of firms $(\beta=$ $0.16, \mathrm{p}=.079$ ). Thus, statistically, Hypothesis $1 \mathrm{c}$ is marginally supported.

Insert Table 3 about here 


\section{Moderation Effects}

In Hypothesis 2 to Hypothesis 5, we predicted that customer responses to CSR, industry competition, the role of government, and managerial incentives would moderate the relationship between the CSR mindsets of managers and the adopted CSR strategies. The results are reported in Table 4, and all significant interaction effects are graphically displayed in Fig. 3 - Fig. 6 using one standard deviation above and below the mean of each of these four moderating variables to represent their high and low values (Aiken and West 1991).

Insert Table 4 and Fig. 3- Fig. 6 about here

In Hypothesis 2, we predicted that the relationship between the CSR mindsets of managers and the CSR strategies of firms would be stronger when firms receive strong customer responses to CSR rather than weak responses. The results show that the interaction of customer responses to CSR and the CSR mindsets of managers have a marginally significant positive effect on the CSR strategies of firms after controlling for all main effects $(\beta=0.18, p=.054)$. In support of our prediction, as shown in Fig 2, the relationship between the CSR mindsets of managers and the CSR strategies of firms is stronger when a high level of customer response to CSR was observed (simple slope $=0.26, \mathrm{t}=1.84, \mathrm{p}=.066$ ), whereas the relationship is weaker when customers have weaker responses to CSR (simple slope $=0.01, \mathrm{t}=0.71$, n.s.). Thus, statistically, Hypothesis 2 received marginal support.

In Hypothesis 3, we anticipated that the relationship between the CSR mindsets of managers and the CSR strategies of firms would be stronger for low levels of industry competition rather than high levels of competition. The results reported in Table 4 suggest that the interaction of industry competition and the CSR mindsets of managers has a significant negative effect on the CSR strategies of firms after controlling for all main effects $(\beta=-0.28, \mathrm{p}=.002)$. Fig 3 shows that the positive relationship between the CSR mindsets of managers and the CSR strategies of firms is stronger when low levels of industry competition are observed (simple slope $=0.36, \mathrm{t}$ $=2.07, \mathrm{p}=.039$ ), whereas the relationship is weaker in the context of high levels of industry competition ( simple slope $=-0.02, \mathrm{t}=-0.15$, n.s.). These results provide support for Hypothesis 3 .

In testing Hypothesis 4, we expected that the relationship between the CSR mindsets of managers and the CSR strategies of firms would be stronger when the role of government is strong rather than weak. The results indicate that the interaction of the role of government and the CSR mindsets of managers has a significant positive effect on the CSR strategies of firms after controlling for all main effects $(\beta=0.31, \mathrm{p}=.001)$. The positive relationship between the CSR mindsets of managers and the CSR strategies of firms (see Figure 4) is stronger when the role of government is larger ( simple slope $=0.33, \mathrm{t}=2.33, \mathrm{p}=.021$ ), whereas the relationship becomes negative when the role of government is smaller, although it is statistically insignificant ( simple slope $=-0.17, \mathrm{t}=-0.14$, n.s.). Therefore, Hypothesis 4 is supported.

Finally, we examined Hypothesis 5, which postulated that the relationship between the CSR mindsets of managers and the CSR strategies of firms would be weaker when CSR-related 
managerial incentives are high. The results suggest that the interaction of managerial incentives and the CSR mindsets of managers has a significant negative effect on the CSR strategies of firms after controlling for all main effects $(\beta=-0.27, \mathrm{p}=.001)$. The positive relationship between the CSR mindsets of managers and the CSR strategies (Fig. 5) of firms is stronger when managerial incentives are low (simple slope $=0.35, \mathrm{t}=2.02, \mathrm{p}=.045$ ), whereas the relationship is weaker when managerial incentives are high (simple slope $=-0.19, \mathrm{t}=-0.11$, n.s.). Therefore, Hypothesis 5 is supported.

A summary of the hypotheses and empirical testing results is presented in Table 5.

Insert Table 5 about here

\section{Discussion and Conclusion}

This paper has sought to contribute to an understanding of how CSR mindsets of managers, who are influenced by political ideologies, may induce managers to adopt a range of strategic responses to CSR. Following the call by Basu and Palazzo (2008) for adopting a sense-making process approach (Weick 1995) to examine managerial cognitive antecedents of CSR, this study underscores the importance of socialist ideology of managers and the significance of considering managerial cognition (i.e., CSR mindset), the firms' external factors (e.g. Greening and Gray, 1994) as well as internal institutional determinants (e.g. Chin et al 2013) to explain how organisations make sense of their worlds (Basu and Palazzo 2008, 122). To this end, we developed and tested a contingency model to understand how and when political ideology of managers affects their decisions on the choice of CSR strategies for their firms. We have emphasised the need to study managerial cognition when attempting to gain insight into how managers make decisions pertaining to CSR strategies, because cognition guides and precedes action. Research on political ideology suggests that because ideologies constitute a central sphere in the belief system, they may mould an individual's entire representation system. With China as our research context, we establish that socialist ideology does seem to have a significant positive impact on CSR confirming the arguments and findings of prior influential studies (e.g. Friedman, 1970; Matten, et al. 2003), but this impact is found to be contingent on the firm's external and internal factors. Our results are generally supportive of the hypothesised relationships developed in our conceptual framework with the empirical data collected from 129 functional and general managers in 43 Chinese companies. Several major findings emerged from this study.

Firstly, socialist ideology is positively associated with the CSR mindsets of managers, which influence a specific CSR strategy (i.e., reactive or proactive) (ranging from reactive, defensive, or accommodative to proactive) that is adopted. Not surprisingly, these managers value their firm's non-economic responsibilities. The results empirically validate our "political ideology CSR mindset - CSR strategy" process model that we proposed in line with the logic of the sensemaking process model (Basu and Palazzo 2008; Weick 1995). Our process model postulates a general theoretical proposition - that is, managers will adhere to a particular 
ideology which will motivate them to strategically respond to CSR via their distributed cognitive systems embodying pro-social tendencies. As such, our process model explains how managers' political ideology affects their choice of CSR strategy for their firms with a focus on the mediation effect of the CSR mindset of managers. Our process model differs from prior 'political ideology - CSR strategy' studies (e.g. Chin, et al 2013; Walters 1977) that looked at the direct effect of political managers' ideology on their choice of CSR strategy.

Secondly, CSR mindsets of managers mediate the relationship between managers' socialist ideology and the CSR strategies of firms with a marginal level of significance. Prior studies explained whether and to what extent political ideologies of managers affect firms' CSR behaviour. Guided by the managerial sense-making perspective (Basu and Palazzo 2008; Weick 1995), this study focuses on the cognitive decision making process and explains how socialist ideology affects CSR decisions via CSR mindset of managers. The results validate Basu and Palazzo (2008)'s theorising that a firm's CSR decisions are made by its managers and are derived from the managers' cognitive mental frameworks (i.e., mindsets) shaping their sense of who they are in their environment. Our results are relatively conservative because of the rather modest sample size. Nevertheless, the responses of 129 middle-level and top-level managers who participated in the survey have shed light on the micro-level cognitive processes involved in making decisions regarding the choice of CSR strategies. The marginal effect may become significant when the sample size is increased.

Thirdly, contrary to our predictions and prior research on customer pressures as an important driver of firm-level CSR efforts, the hypothesis that the relationship between CSR mindsets and CSR strategy is positively moderated by customer responses to CSR received only marginal support. This finding may suggest that a socialist oriented CSR mindset that is underpinned by the values and beliefs of a socialist ideology may override extrinsic influences such as customer pressures.

Fourthly, consistent with prior findings (for a review, see Moon and Shen 2010) and our hypothesis, government was found to be a key driver of CSR. Our tests suggest a strong positive moderating effect on the relationship between the CSR mindsets of managers and the CSR strategy adopted by firms. In the situation where there is a shared ideology between the government and managers (i.e., socialist ideology in this context), socialist ideologies of managers and government act in tandem to promote a stronger socialist oriented CSR mindset of managers, resulting in a proactive CSR strategy adopted by firms.

In addition, while industry competition was found to eliminate the positive effect of CSR mindset on CSR choice of managers as hypothesised, the direct effect of industry competition on CSR strategy is also significant, but positive. The direct and positive effect of industry competition on CSR behaviour of firms is consistent with the strategic view of CSR, in that firms in more competitive environments have more incentives to invest in social actions while simultaneously being able to "do well by doing good". This is because they may benefit from higher employee motivation, access to new market segments (such as "green" consumers), the more efficient use of materials and energy, and so on (e.g., Hart 1995; Jones 1995; McWilliams et al., 2006; Porter and Kramer 2006, 2011; Russo and Fouts, 1997). Although the rationales behind the strategic view of CSR (extrinsically motivated and reactive) and the socialist ideology view of CSR (intrinsically motivated and proactive) which we have examined in this study may differ fundamentally, they are likely to result in similar outcomes. On the other hand, 
high industry competition may challenge the fundamental beliefs and values held by managers and hence their socialist ideology, leading to unethical behaviours. This is consistent with the view that competitive pressures are likely to lead to the spread of censured activities (e.g., corruption, excessive executive pay and earnings manipulation) (Sheleifer 2004). It follows that the ever-competitive environment in China may well be one of the root causes of unethical behaviours of Chinese firms, as discussed in the early section of this paper. Consequently, the findings of this study are inconsistent with the literature that views CSR as an unnecessary cost of doing business (e.g., Elhauge 2005, Friedman 1970). It is also interesting to note that the dual effects of industry competition on CSR, either direct or indirect, are significant only when the other factors are controlled for.

Finally, consistent with our prediction, CSR-related managerial incentives negatively influence the relationship between CSR mindset and CSR strategy, suggesting that the incentives and pro-CSR mindsets of managers may be substitutes for one another. Therefore, when a manager has an embedded pro-socialist political ideology, incentives for conducting CSR activities are not required. This finding is largely inconsistent with the findings of prior studies (e.g. Berrone and Gomez-Meija 2009; Deckop, et al. 2006) that were based on samples of firms operating in developed markets. Our theoretical argument in the conceptual section of this paper was that CSR initiatives of Chinese managers are likely to be motivated intrinsically rather than extrinsically. Such intrinsic motivation may be due to a synergistic effect of mainstream Chinese values originating in spirituality, collectivism, and Confucianism, and socialist ideology which downplays monetary-based incentives.

The empirical finding in the context of China suggests that agency theory appears to have limited explanatory power, especially when managers strongly uphold socialist ideology. These managers may not narrowly see themselves as agents of shareholders, but rather, in line with "The Mao Zedong Thought", acting in the interests of the broader society. One of the most influential principles underpinning Maoism (Mao 1991) is that people are the legitimate owners of the country, because it is people who create wealth. As the state's power belongs to people, people should have the right to govern the country, the army, enterprises, and educational and cultural institutions (Mao 1991; 1999). Therefore, in Mao Zedong's view, people are the main principals of enterprises under socialism (Gong 1974). This 'people's ownership perspective' central to Maoism greatly motivated Chinese citizens to participate in building a socialist China during Mao's era, and the legacy of "The Mao Zedong Thought" still influences the Chinese people today (Yang and Stening 2012).

Our study underscores the significance of considering managerial cognition and contextual variables when studying CSR strategies of firms. We hope that our research will help to address some of the issues in CSR literature that were raised in an influential article by Margolis and Walsh (2003: 278) who argued that there is a need to develop more comprehensive models that incorporate omitted variables and test mediating mechanisms and contextual conditions. Our study thus contributes to a better understanding of the ever-important issue of the nature of the relationship among corporations, markets, and governments.

\section{Limitations and Future Research Direction}

This study is not without limitations; and some of these limitations present opportunities for further research. Firstly, although our research model includes four moderators, both internal 
and external to the firm, it is by no means comprehensive. We have not been able to include other stakeholders that have been theoretically and empirically shown to influence firm-level engagement in CSR, such as non-government organisations, suppliers, and capital markets/investors (e.g., Freeman 1984; Donaldson and Preston 1995). Contemporary firms and their managers evolve in complex networks of stakeholders of a diverse nature that certainly contribute to orienting the creation and interpretation of CSR-related meaning by managers. Because managers have a particular cognitive platform (a resource-dependence platform, a social issue platform, or a societal-sector platform) in mind when they engage with a stakeholder (Athanasopoulou and Selsky 2015), it is reasonable to expect that these cognitive platforms may moderate the CSR mindset-strategic outcome relationship that is central to our model.

Secondly, because our theoretical framework is far from exhaustive, the study opens up a new line of research into the effects and interplay of political ideologies, CSR mindsets and CSR strategies. We believe that three specific theoretical extensions are particularly worthy of further investigation. Various types of political ideologies can co-exist in a particular national context and directly and/or indirectly affect CSR outcomes of firms. Future research may investigate how other political ideologies such as capitalism, liberalism, conservatism, democratic socialism and the like affect CSR mindsets and/or CSR decision- making of managers. Researchers could also consider how a much wider range of variables related to the resources and dynamic capabilities of firms (Teece, 1997) and dynamic managerial capabilities (Adner and Helfat, 2003; Kor \& Mesko, 2013) may affect or moderate the 'political ideology CSR decision-making' relationship. Firm resources, distinctive competencies, size, age, ownership structures and dynamic managerial capabilities may either enable or limit a firm' propensity to engage in CSR activities. Managerial cognitive personality (an aspect of cognitive capability), prior experience, education and training (aspects of human capital capability), professional affiliation, political party membership or affiliation (aspects of social capital capability) can guide and influence managerial decision making and strategy implementation (Adner and Helfat, 2003).

Thirdly, although our model integrates concepts from various perspectives, it is not multilevel in a conventional sense; hence it would be of particular value to engage in a genuinely multi-level study (see Aguilera et al. 2007). Multi-level models may incorporate or combine different theoretical perspectives as antecedents or main effect independent variables, such as institutional (external social context), cultural (organisational level), and cognitive (individual level) perspectives, as in the study of Athanasopoulou and Selsky (2015), or institutions, industry conditions, and firm resources in the research of Peng (2009). It is advisable that further empirical research should capture the multi-level CSR-related opinions, perceptions, behaviours, and strategic responses within organisations; such an endeavour could include surveying employees, functional-level managers, and top management teams. The strength of such research has been recently demonstrated in the work of Schaubroeck et al. (2012) linking ethical leadership with ethical culture both across and within organisational levels by examining how both leadership and culture relate to the ethical cognitions and behaviours of low-level followers. A multi-level approach to studying compositional constructs, such as "ethical culture" or the CSR mindset, is more robust methodologically (Kozlowski and Klein, 2000) and 
may also produce novel or unexpected findings that are relevant to both theory and practice (Aguilera et al. 2007; Schaubroeck et al. 2012).

Fourthly, the empirical findings pertaining to the effect of managerial incentives in this study have challenged the empirical validity of agency theory in the Chinese context, and the theoretical reasoning laid out in the previous section will require further explicit validation. This line of enquiry may potentially provide an avenue for theorising and empirically investigating how different cultures, religious values and norms, and political ideologies influence the effectiveness of managerial incentives on CSR-related decisions from a managerial cognitive perspective.

Finally, we are unable to fully demonstrate the validity and credibility of 43 items of 6 measures owing to a relatively small sample $(n=129$ general and functional managers working 43 machinery manufacturing companies). To enhance the findings of this study, future research should also consider using other statistical procedures such as confirmatory factor analysis to further validate the factor structure of all constructs and demonstrate the distinctiveness of each construct using a diverse and a relatively bigger sample drawn from companies in different industries and in different countries.

\section{References}

Adner, R., \& Helfat, C. E. (2003). Corporate effects and dynamic managerial capabilities. Strategic Management Journal, 24: 1011-1025.

Adorno, T. W., Frenkel-Brunswik, E., Levinson, D. J., \& Sanford, R. N. (1950). The authoritarian personality. New York: Harper \& Row.

Agle, B. R., Mitchell, R. K., \& Sonnenfeld, J. A. (1999). Who matters to CEOs? An investigation of stakeholder attributes and salience, corporate performance, and CEO values. Academy of Management Journal, 42(5): 507-525.

Aguilera, R. V., Rupp, D. E., Williams, C. A., \& Ganapathi, J. (2007). Putting the S back in corporate social responsibility: A multi-level theory of social change in organizations. Academy of Management Review, 32(3): 836-863.

Aguinis, H., \& Glavas, A. (2012). What we know and don't know about corporate social responsibility: A review and research agenda", Journal of Management, 38(4): 932-968.

Aiken, L. S., \& West, S. G. (1991). Multiple Regression: Testing and Interpreting Interactions. Newbury Park, CA: Sage.

Aitkenhead, A., \& Slack, J. (1985). Issues in cognitive modelling. London: Erlbaum in association with the Open University.

Albareda, L., Ysa, T., \& Lozano, J. M. (2005). The role of governments in fostering CSR. In A. Kakabadse \& M. Morsing (ed.), Corporate social responsibility, reconciling aspiration with application. Houndmills: Palgrave.

Aragón-Correa, J. A., \& Sharma, S. (2003). A contingent resource-based view of proactive corporate environmental strategy. Academy of Management Review, 28(1): 71-88.

Athanasopoulou, A., \& Selsky, W. J. (2015). The social context of corporate social responsibility: Enriching research with multiple perspectives and multiple levels. Business \& Society, 54(3): 322-364. 
Bartunek, J. M. (1984). Changing interpretive schemes and organizational restructuring: The example of a religious order. Administrative Science Quarterly, 29(3): 355-372.

Basu, K., \& Palazzo, G. (2008). Corporate social responsibility: A process model of sense making. Academy of Management Review, 33(1): 122-136.

Beach, L. R. \& Mitchell, T. R. (1978). A contingency model for the selection of decision strategies. Academy of Management Review, 3(3): 439-449.

Berrone, P., \& Gomez-Mejia, L. R. (2009). Environmental performance and executive compensation: An integrated agency-institutional perspective. Academy of Management Journal, 52(1): 103-126.

Besser, T. L., \& Miller, N. J. (2011). The company they keep: How formal associations impact business social performance. Business Ethics Quarterly, 21(3): 503-525.

Bhattacharya, C. B., \& Sen, S. (2003). Consumer-company identification: A framework for understanding consumers' relationships with companies. Journal of Marketing, 67(April): 76-88.

Bjørnskov, C., \& Paldam, M. (2012). The spirits of capitalism and socialism. Public Choice, 150 (3-4): 469-498.

Bloom, M. (2004). The ethics of compensation systems. Journal of Business Ethics, 52(2): 149 -152 .

Boal, K. B., \& Peery, N. (1985). The cognitive structure of corporate social responsibility. Journal of Management, 11(3): 71-82.

Brown, T., \& Dacin, P. A., (1997). The company and the product: Corporate associations and consumer product responses. Journal of Marketing, 61(1): 68-84.

Browne, J., \& Nuttall, R. (2013). Beyond corporate social responsibility: Integrated external engagement. Insights \& Publications. McKinsey\&Company

Cai, Y., Jo, H., and Pan, C. (2011). Vice or virtue? The impact of corporate social responsibility on executive compensation. Journal of Business Ethics, 104(2): 159-173.

Campbell, J. L. (2007). Why would corporations behave in socially responsible ways? An institutional theory of corporate social responsibility. Academy of Management Review, 32(3): 946-967.

Carroll, A. B. (1979). A three-dimensional conceptual model of corporate performance. Academy of Management Review, 4(4): 497-505.

Chin, M. K., Hambrick, D. C., \& Trevino, L. K. (2013). Political ideologies of CEOs: Illustrative evidence of the influence of executive values on corporate social responsibility. Administrative Science Quarterly, 58(2): 197-232.

Chow, G. C. (2015). China's economic transformation. West Susses, UK: John Wiley \& Sons Limited.

Comrey, A. L., \& Lee, H. B. (1992). A first course in factor analysis. Hillsdale, NJ: Erlbaum.

CSR ASIA. (2015). A study on corporate social responsibility development and trends in

China. Beijing, Embassy of Sweden.

Daft, R. L., \& Weick, K. E. (1984). Toward a model of organizations as interpretation systems. Academy of Management Review, 9(2): 284-295. 
Davis, K. (1973). The case for and against business assumption of social responsibilities. Academy of Management Journal, 16(2): 312-322.

Deckop, J. R., Merriman, K. K., \& Gupta, S. (2006). The effects of CEO pay structure on corporate social performance. Journal of Management, 32(3): 329-342.

DiMaggio, P. J., \& Powell, W. W. (1983). The iron cage revisited: Institutional isomorphism and collective rationality in organizational fields. American Sociological Review, 48(2): 147-160.

Donaldson, T., \& Preston, L. E. (1995). The stakeholder theory of the corporation: Concepts, evidence, and implications. Academy of Management Review, 20(1): 65-91.

Edelman, D. C. (2010). Branding in the Digital Age: You're Spending Your Money in All the Wrong Places. Harvard Business Review, 88(12): 62-69.

Eisenhardt, K. M. (1989). Agency theory: An assessment and review. Academy of Management Review, 14(1): 57-74.

Elhauge, E. (2005). Sacrificing corporate profits in the public interest. New York University Law Review, 80(3): 733-869.

Erikson, R. S., Luttbeg, N. R., \& Tedlin, K. L. (1988). American public opinion: Its origins, content, and impact. New York: Macmillan.

Estrin, S. (2002). Competition and corporate governance in transition. Journal of Economic Perspectives, 16(1): 101-124.

Fligstein, N. (1991). The structural transformation of American Industry: An institutional account of the causes of diversification in the largest firms, 1919-1979. In W. W. Powell \& P. J. DiMaggio (Eds.), The new institutionalism in organizational analysis (311-336). Chicago, IL: University of Chicago.

Fombrun, C. J., Gardberg, N. A., \& Barnett, M. L. (2000). Opportunity platforms and safety nets: Corporate citizenship and reputational risk. Business and Society Review, 105(1): 85-106.

Ford, R., \& McLaughlin, F. (1984). Perceptions of socially responsible activities and attitudes: A comparison of business school deans and corporate chief executives. Academy of Management Journal, 27(3): 666-674.

Fox, T., Ward, H. \& B. Howard (2002). Public sector roles in strengthening corporate social responsibility: A baseline study. Washington: The World Bank.

Freeman, E. R. (1984). Strategic management: A stakeholder approach. Boston, MA: Pitman.

Friedman, M. (1970). The social responsibility of business is to increase its profits. New York Times, September 13.

Fromm, E. (1963). Marx's concept of man. New York: Frederick Ungar.

Gong, X. W. (1974). Socialism enterprise management. Shanghai: Shanghai People's Publishing House.

Granovetter, M. (1985). Economic action and social structure: The problem of embeddedness. American Journal of Sociology, 91(3): 481-510.

Greening, D. W., \& Gray, B. (1994). Testing a model of organizational responses to social and political issues. Academy of Management Journal, 37(3): 467-498. 
Guadagnoli, E., \& Velicer, W. (1988). Relation of sample size to the stability of component patterns. Psychological Bulletin, 103(2): 265-275.

Handelman, J. M., \& Arnold, S. J. (1999). The role of marketing actions with a social dimension: Appeals to the institutional environment. Journal of Marketing, 63(July): 3348.

Hart, S. L. (1995). A natural-resource-based view of the firm. Academy of Management Review, 20(4): 966-1014.

Hay, R., \& Gray, E. (1974). Social responsibilities of business managers. Academy of Management Journal, 17(1): 135-143.

Hemingway, C. A., \& Maclagan, P. W. (2004). Managers' personal values as drivers of corporate social responsibility. Journal of Business Ethics, 50(1): 33-44.

Henriques, I. \& Sadorsky, P. (1999). The relationship between environmental commitment and managerial perceptions of stakeholder importance. Academy of Management Journal, 42(1): 87-99.

Hoffman, A. J. (1999). Institutional evolution and change: Environmentalism and the US chemical industry. Academy of Management Journal, 42(4): 351-370.

Hoffman, A., \& Bazerman, M. (2006). Changing practice on sustainability: Understanding and overcoming the organizational and psychological barriers. In B. Husted (Ed.), Organizations and the sustainability mosaic: Crafting long-term ecological and societal solutions (pp. 84-105). Cheltenham, UK: Edward Elgar Publishing.

Huang, Y. (2008). Capitalism with Chinese characteristics: Entrepreneurship and the state. New York: Cambridge University Press.

Ip, P. K. (2009). The challenge of developing a business ethics in China. Journal of Business Ethics, 88(1): 211-224.

Jaworski, B. J., \& Kohli, A. K. (1993). Market orientation: Antecedents and consequences. Journal of Marketing, 57(3): 53-70.

Jen, C. H. (1970). The introduction of Marxism-Leninism into China: The early years, 19191924. Studies in Soviet Thought, 10: 138-166.

Jensen, M. C. (2002). Value maximization, stakeholder theory, and the corporate objective function. Business Ethics Quarterly, 12(2): 235-256.

Jensen, M. H. (2006). Serve the people! Corporate social responsibility (CSR) in China. Copenhagen Discussion Papers, 2006-6 (Asia Research Center). Assessed on 16 January 2015 at http://openarchive.cbs.dk/bitstream/handle/10398/7405/cdp\%202006-006.pdf

Jiang, Q. J., \& Shu, Y. (2011). Corporate social responsivity perspective in risk management of food enterprise. Shanghai: Shanghai People's Publishing House.

Jiang, F., and Stening, W. B. (2013). Do indigenous firms incur a liability of localness when operating in their home market? The case of China. Journal of World Business, 48(4): 478-489.

Jones, T. M. (1995). Instrumental stakeholder theory: A synthesis of ethics and economics. Academy of Management Review, 20(2): 404-437.

Jost, J. T. (2006). The end of the end of ideology. American Psychologist, 61(7): 651-670.

Jost, J., \& Amodio, D. (2012). Political ideology as motivated social cognition: Behavioral and neuroscientific evidence. Motivation $n$ and Emotion, 36(1): 55-64. 
Jost, J. T., Blount, S., Pfeffer, J., \& Hunyady, G. (2003). Fair market ideology: Its cognitivemotivational underpinnings. Research in Organizational Behavior, 25: 53-91.

Jost, J. T., Federico, S. M., \& Napier, J. L. (2009). Political ideology: Its structure, functions, and elective affinities. Annual Review of Psychology, 60: 307-337.

Kitzmueller, M. (2008). Economics and corporate social responsibility. European University Institute Department of Economics Working Paper ECO 2008/37, October. Florence, Italy: European University Institute Department of Economics. http://cadmus.eui.eu/bitstream/handle/1814/9816/ECO_2008_37.pdf?sequence=1.

Kor, Y. Y., \& Mesko, A. (2013). Dynamic managerial capabilities: Configuration and orchestration of top executives' capabilities and the firm's dominant logic. Strategic Management Journal, 34: 233-244.

Kozlowski, S. W. J., \& Klein, K. J. (2000). A multilevel approach to theory and research in organizations: Contextual, temporal, and emergent processes. In K. J. Klein \& S. W. J. Kozlowski (Eds.), Multilevel theory, research and methods in organizations: foundations, extensions, and new directions (pp. 3-90). San Francisco, CA: Jossey-Bass.

Le Menestrel, M., van den Hove, S., \& de Bettignies, H.-C. (2002). Processes and consequences in business ethical dilemmas: The oil industry and climate change. Journal of Business Ethics, 41(3): 251-266.

Leach, R. (1993). Political ideologies: An Australian introduction. South Melbourne: Macmillan Education Australia.

Lenin, V. (1917). Imperialism, the Highest Stage of Capitalism (Империализм как высшая стадия капитализма). Russian Soviet Federative Socialist Republic: Zhizn'I znanie.

Lie, E. (2005). The timing of CEO stock option awards, Management Science, 51(5): 802-812.

Lin, L. W. (2010). Corporate social responsibility in China. Berkeley Journal of International Law, 28(1): 64-100.

Luo, X., \& Bhattacharya, C. B. 2006. Corporate social responsibility, customer satisfaction, and market value. Journal of Marketing, 70(4): 1-18.

Luo, Y. (2007). From foreign investors to strategic insiders: Shifting parameters, prescriptions and paradigms for MNCs in China. Journal of World Business, 42(1): 14-34.

Mahoney, L. S., \& Thorn, L. (2006). An examination of the structure of executive compensation and corporate social responsibility: A Canadian investigation. Journal of Business Ethics, 69(2): 149-162.

Mao, T. T. (1967). Selected Works of Mao Tse-Tung (Vol. 2). Beijing: Foreign Language Press.

Mao, Z. D. (1991). Selected works of Mao Zhedong, vol. 3. Beijing: People's Publishing House. (In Chinese).

Mao, Z. D. (1999).Selected works of Mao Zhedong, vol. 8. Beijing: People's Publishing House. (In Chinese).

Margolis, J., \& Walsh, J. (2003). Misery loves companies: Rethinking social initiatives by business. Administrative Science Quarterly, 48(2): 268-305. 
Marx, K. (1844/1969). The economic and philosophic manuscripts of 1844. New York: International Publishers.

McGuire, J., Dow, S., \& Argheyd, K. (2003). CEO incentives and corporate social performance. Journal of Business Ethics, 45(4): 341-359.

Maignan, I. (2001). Consumers' perceptions of corporate social responsibilities: A crosscultural comparison. Journal of Business Ethics, 30(1): 57-72.

Marx, K., \& Engels, F. (1878/2009). Communist manifesto, wages price and profit, capital, socialism: Utopian and scientific. Cirencester: CRW Publishing Limited.

Matten, D., Crane, A., \& Chapple, W. (2003). Behind the mask: Revealing the true face of corporate citizenship. Journal of Business Ethics, 45(1-2): 109-120.

McWilliams, A., \& Siegel, D. (2001). Corporate social responsibility: A theory of the firm perspective. Academy of Management Review, 26(1): 117-127.

McWilliams, A., Siegel, D., \& Wright, P. (2006). Corporate social responsibility: Strategic implications. Journal of Management Studies, 43(1): 1-18.

Michel, A. A. (2007). A distributed cognition perspective on newcomers' change processes: The management of cognitive uncertainty in two investment banks. Administrative Science Quarterly, 52(4): 506-557.

Midttun, A. (2005), Realigning business, government and civil society: Emerging embedded relational governance beyond the (neo) liberal and welfare state models. Corporate Governance: The International Journal of Business in Society, 5(3): 159-74.

Moon, J., \& Shen, X. (2010). CSR in China research: Salience, focus and nature. Journal of Business Ethics, 94(4): 613-629.

Morgan, G. 2007. Images of organization, Thousand Oaks: Sage

Murillo-Luna, J. L., Garcés-Ayerbe, C., \& Rivera-Torres, P. (2008). Why do patterns of environmental response differ? A stakeholders' pressure approach. Strategic Management Journal, 29(11): 1225-1240.

Murtha, T., \& Lenway, S. (1994). Country capabilities and the strategic state: How national political institutions affect multinational corporations' strategies. Strategic Management Journal, 15 (Supplement S2): 113-129.

North, D. C. (1990). Institutions, institutional change and economic performance. Cambridge, United Kingdom, and New York: Cambridge University Press.

Ostlund, L. E. (1977). Attitudes of managers toward corporate social responsibility. California Management Review, 19(4), 35-49.

Parsons, T. (1951). The social system. New York, NY: Free Press.

Peng, M. W. (2009). Global strategy, $2^{\text {nd }}$ ed. Mason, OH: South-Western.

Peng, M. W., Wang, D. Y. L., \& Jiang, Y. (2008). An institution-based view of international business strategy: a focus on emerging economies. Journal of International Business Studies, 39(5): 920-936.

Porter, M. E. (2008). The five competitive forces that shape strategy. Harvard Business Review, 86(1): 78-93. 
Porter, M. E., \& Kramer, M. R. (2006). Strategy and society: The link between competitive advantage and corporate social responsibility. Harvard Business Review, 84(12): 78-92.

Porter, M. E., \& Kramer, M. R. (2011). The big idea: Creating shared value. Harvard Business Review, 89(1-2): 62-77.

Potts, M. (2006). CEO compensation and virtue ethics. In R.W. Kolb (Ed.) The ethics of executive compensation. Oxford: Blackwell Publishing Ltd.

Preacher, K. J., \& Hayes, A. F. (2004). SPSS and SAS procedures for estimating indirect effects in simple mediation models. Behavior Research Methods, Instruments, \& Computers, 36(4): 717-731.

Redding, G., \& Witt, M. A. (2007). The future of Chinese capitalism: Choices and chances. Oxford: Oxford University Press.

Reinhardt, F. L., Stavins, R. N., \& Vietor, R. H. K. (2008). Corporate social responsibility through an economic lens. Review of Environmental Economics and Policy, 2(2): 219239.

Richins, M. L., and Rudmin, F. W. (1994). Materialism and economic psychology. Journal of Economic Psychology, 15: 217-231.

Roe, M. J. (1994). Strong managers, weak owners: The political roots of American corporate finance. Oxford: Oxford University Press.

Roe, M. J. (2003). Political determinants of corporate governance: Political context, corporate impact. New York: Oxford University Press.

Roper, J. P., \& Hu, H. (2005). Modern Chinese Confucianism: A model for western human capital development? $4^{\text {th }}$ Annual Colloquium of European Academy of Business in Society, Warsaw.

Russo, M. V. \& Fouts, P. A. (1997). A resource-based perspective on corporate environmental performance and profitability. Academy of Management Journal, 40(3): 534-559.

Savage, G. T., Nix, T. W., Whitehead, C. J., \& Blair, J. D. (1991). Strategies for Assessing and Managing Organizational Stakeholders. Academy of Management Executive, 5 (2): $61-75$.

Schein, E. H. (1984). Corporate culture: Constraint or opportunity for strategy. PA Journal of Management Issues, 1(1): 4-10.

Schaubroeck, M. J., Hannah, T. S., Avolio, J. B., Kozlowski, W. J. S., Lord, G. R., Treviño, K. L., Dimotakis, N., and Peng, C. A. (2012). Embedding ethical leadership within and across organization levels. Academy of Management Journal, 55(5): 1053-1078.

Schwartz, S. H. (1994). Are there universal aspects in the content and structure of values? Journal of Social Issues, 50(4): 19-45.

Schweickart, D., Lawler, J., Ticktin, H., \& Ollman, B. (1998). Market socialism: The debate among socialists. London: Routledge.

Scott, W. R. (1981). Organizations: Rational, Natural, and Open Systems. Englewood Cliffs NJ: Prentice Hall Inc.

Scott, W. R. (2001). Institutions and organizations, $2^{\text {nd }}$ ed. Thousand Oaks, CA: Sage.

Secchi, D. (2009). The cognitive side of social responsibility. Journal of Business Ethics, 88(3): $565-581$. 
Sen, S., Bhattacharya, C. B., \& Korschun, D. (2006). The role of corporate social responsibility in strengthening multiple stakeholder relationships: A field experiment. Journal of the Academy of Marketing Science, 34(2), 158-66.

Sharma, S. (2000). Managerial interpretations and organizational context as predictors of corporate choice of environmental strategy. Academy of Management Journal, 43(4): 681-697.

Sharma, S. \& Vredenburg, H. (1998). Proactive corporate environmental strategy and the development of competitively valuable organizational capabilities. Strategic Management Journal, 19(8): 729-753.

Shleifer, A. (2004). Does competition destroy ethical behavior? American Economic Review, 94(2): 414-418.

Short, J. (2004). Are we wasting time with the corporate social performance-financial performance link? Paper presented at the national meetings of the Academy of Management, New Orleans, LA.

Sidorov, A., Alexeyeva, I., \& Shklyarik, E. (2000). The ethical environment of Russian business, Business Ethics Quarterly, 10(4): 911-924.

Simon, H. A. (1957). Administrative behavior. New York, NY: MacMillan.

Solomon, R. C. (1993). Ethics and excellence: Cooperation and integrity in business. New York: Oxford University Press.

Steinbruner, J. D. (1974). The cybernetic theory of decision: New dimensions of political analysis. Princeton, NJ: Princeton University Press.

Stevens J. P. (1992). Applied multivariate statistics for the social sciences, $2^{\text {nd }}$ ed. Hillsdale, NJ: Erlbaum.

Stiglitz, J. E. (1992). Some theoretical aspects of the privatization: Applications to Eastern Europe. Rivista di Politica Economica, 12: 179-204.

Stout, L. (2012). Killing Conscience: The unintended behavioral consequences of 'pay for performance', Cornell School of Law working paper, March.

Sturdivant, F. D. (1979). Executives and activists: Test of stakeholder management. California Management Review, 12(1): 5-39.

Szalay, L. B., \& Kelly, R. M. (1982). Political ideology and subjective culture: Conceptualization and empirical assessment. American Political Science Review, 76(3): 585-602.

Tabachnick, B. G., \& Fidell, L. S. (2007). Using multivariate statistics, 5th ed. Boston: Pearson Education Inc.

Teece, D., Pisano, G., \& Shuen, A. (1997). Dynamic capabilities and strategic management. Strategic Management Journal, 18(7): 509-533.

Tetlock, P. (2000). Cognitive biases and organizational correctives: Do both disease and cure depend on the politics of the beholder? Administrative Science Quarterly, 45:293-326.

Thagard, P. (2008). Cognitive Science, in Edward N. Zalta (ed.). The Stanford encyclopaedia of philosophy. The Metaphysics Research Lab, Center for the Study of Language and Information, Stanford University, Stanford, CA, 
Tversky, A., \& Kahneman, D. (1974). Judgment under uncertainty: Heuristics and biases. Science. New Series, 185(4157): 1124-1131.

Ullmann, A. A. (1985). Data in search of a theory: A critical examination of the relationships among social performance, social disclosure, and economic performance of US firms. Academy of Management Review, 10(3): 540-557.

Waddock, S., \& Graves, S. (1997). The corporate social performance-financial performance link. Strategic Management Journal, 18(4): 303-319.

Waldman, D. A., et al. (2006). Cultural and leadership predictors of corporate social responsibility values of top management: A GLOBE study of 15 countries. Journal of International Business Studies, 37(6): 823-837.

Walsh, J. O. (1995). Managerial and organizational cognition: Notes from a trip down memory lane. Organization Science, 6(3): 280-321.

Walsh, J. P. (2005). Book review essay: Taking stock of stake holder management. Academy of Management Review, 30(2): 426-452.

Walsh, J. P. \& Charalambides, L. C. (1990). Individual and social origins of belief structure change. Journal of Social Psychology, 130 (4): 517-532.

Walters, K. D. (1977). Corporate social responsibility and political ideology. California Management Review, 19(3): 40-51.

Wang, M. (1997). Social development and improvement of the moral quality of city-dwellers. In Wang, M., Yu X., Manuel, B. D. (eds.). Civil Society in a Chinese Context, Chinese Philosophy Studies, XV. Cultural Heritage \& Contemporary Change Series III, ASIA, 15(6): 79-86. Washington, D. C.: The Council for Research in Values and Philosophy.

Wartick, S. L., \& Cochran, P. L. (1985). The evolution of the corporate social performance model. Academy of Management Review, 10(4): 758-769.

Weick, K. E. (1995). Sensemaking in organizations. Thousand Oaks, CA: Sage.

Williams, C. A., \& Aguilera, R. (2008). Corporate social responsibility in a comparative perspective. In A. Crane, A. McWilliams, D. Matten, J. Moon, \& D. Siegel (Eds.), The Oxford handbook of corporate social responsibility (452-472). Oxford: Oxford University Press.

Wilson, J. Q. (1995). Political organizations. New Jersey: Princeton University Press.

Wood, D. J. (1991). Corporate social performance revisited. Academy of Management Review, 16(4): 691-718.

Yang, S., \& Stening, W. B. (2012). Cultural and ideological roots of materialism in China. Social Indicators Research, 108(3): 441-452.

Yang, S., \& Stening, W. B. (2013). Mao meets the market reconciling ideology and pragmatism in China. Management International Review, 53(3): 419-448.

Yang, X. (2007). Li Rugang: Generational change in social responsibility, humanised management and organizational culture. China Fashion, 11 June.

Yau, O. H. M. (1994). Consumer behaviour in China: Customer satisfaction and cultural values. London: Routledge.

$\mathrm{Yu}$, A. B. (1996). Ultimate life concerns, self and Chinese achievement motivation. In M. H. Bond (Ed.), The handbook of Chinese psychology (pp. 227-246). Hong Kong: Oxford University Press. 
Zadek, S., Forstater M., Yu, K. (2012). Corporate responsibility and sustainable economic development in China: Implications for business, US Chamber of Commerce.

Zenisek, T. J. (1979). Corporate social responsibility: A conceptualization based on organizational literature. Academy of Management Review, 4(3): 359-368.

Zheng, Y. (1997). The compilation of three religions: Confucianism, Taoism and Buddhism. Taipei: Zheng Yishan (in Chinese).

Zhao, J. C. (2014). Corporate social responsibility in contemporary China. Cheltenham, UK: Edward Elgar Publishing.

Zollo, M., Minoja, M. Casanova, L., Hockerts, K., Neergard, P., Schneider, S., \& Tencanti, A. (2009). Context: External Strategy and internal capability. Towards an internal change management perspective of CSR: Evidence from project RESPONSE on the sources of the cognitive alignment between managers and their stakeholders, and their implications for social performance. Corporate Governance, 9(4): 355-372. 
Decision making context (Macro and meso level decision making environment)

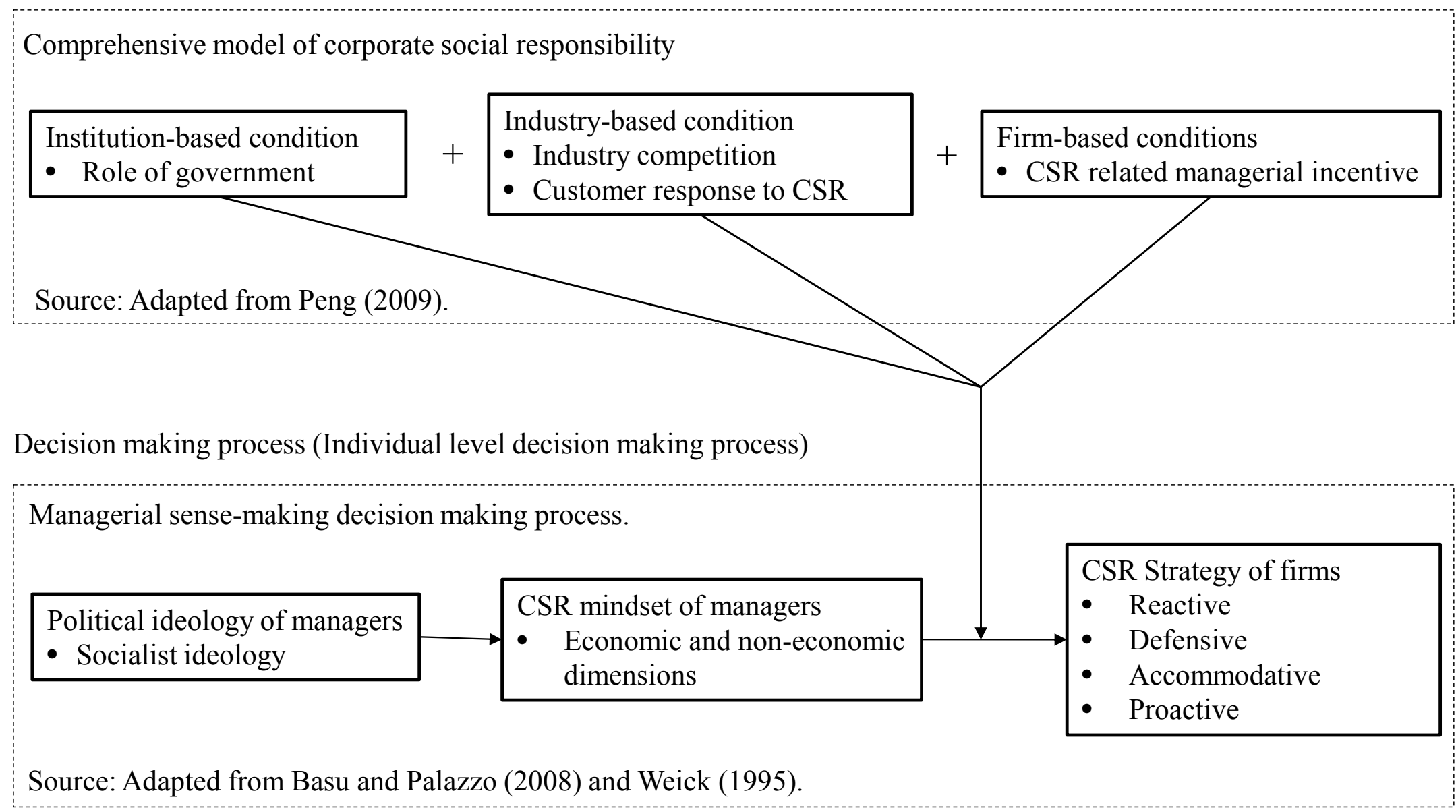

Fig. 1 Synthesis of Theoretical Underpinnings Informed by Contingency Theory 


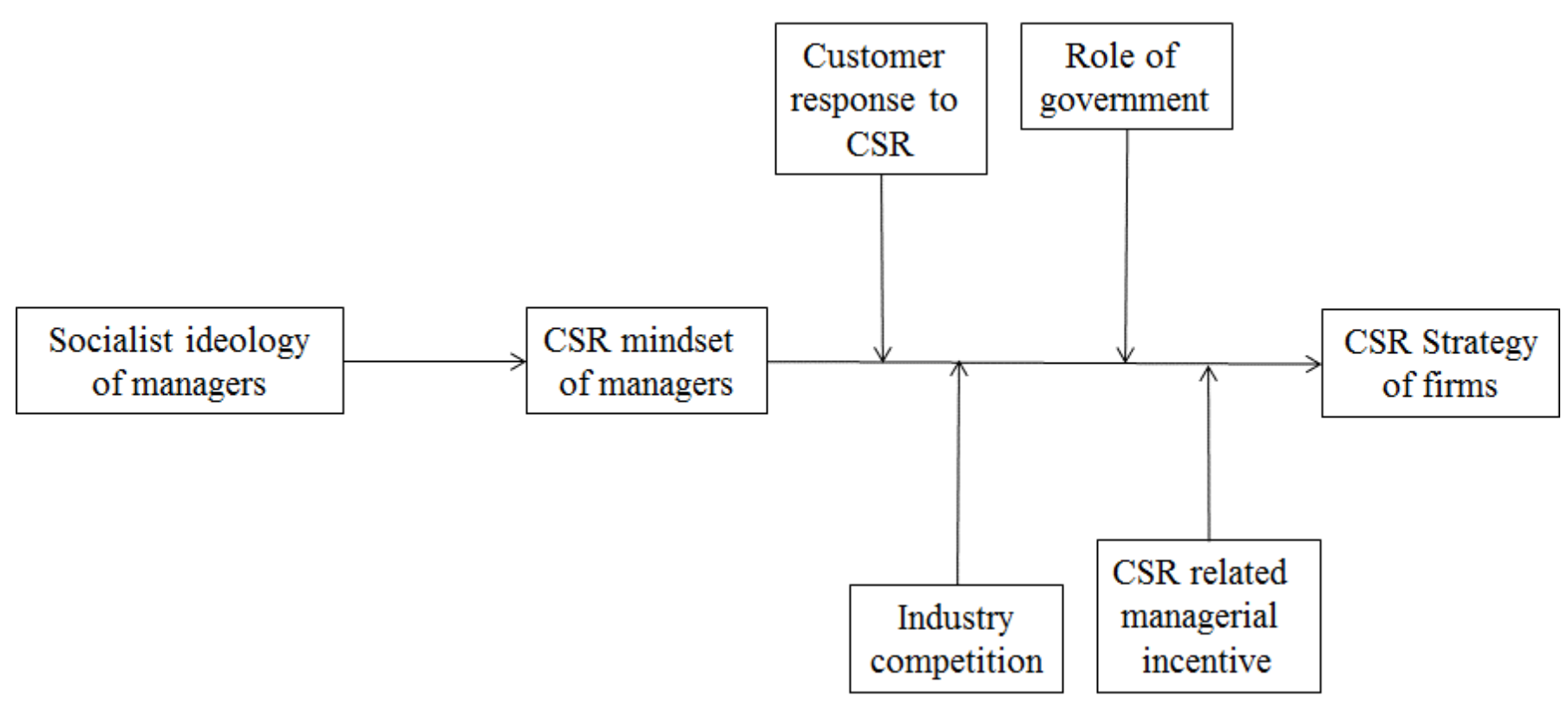

Fig. 2 A Contingent Framework of Political Ideology, CSR Mindset, and CSR Strategy 
Table 1 Examples of Chinese Firms Pursuing Four Alternative CSR Strategies

\begin{tabular}{|c|c|}
\hline CSR Strategy & Example of Firm Responses \\
\hline $\begin{array}{l}\text { Reactive } \\
\text { strategy }\end{array}$ & $\begin{array}{l}\text { A well-known example of such reactive stance toward CSR is Sanlu Group, a Shijiazhuang-based multibillion dollar Chinese } \\
\text { company that was at the centre of the food safety scandal in } 2008 \text { over the use of melamine in milk and infant formula. The scandal } \\
\text { broke after sixteen infants in Gansu Province, who had been fed on milk powder produced by Sanlu Group, were diagnosed with } \\
\text { kidney stones. One of the largest Chinese companies producing dairy products, Sanlu Group was perceived by consumers as a high } \\
\text { quality dairy producer before the incident. However, when market competition intensified, Sanlu increasingly adopted a short-term } \\
\text { focus on maximising profitability. Even after the incident the company did not take any responsible action (such as product recall); } \\
\text { rather, senior management made a secret deal with suppliers to cover up the wrong doing and used the corporate website to deny } \\
\text { the negative publicity. The senior executives argued that, because the group was making a significant contribution to the local } \\
\text { economy, they should be immune from prosecution (Jiang and Shu 2011). }\end{array}$ \\
\hline $\begin{array}{l}\text { Defensive } \\
\text { Strategy }\end{array}$ & $\begin{array}{l}\text { A case in point is Guan Sheng Yuan Group Limited (GSL), a Shanghai-based flagship enterprise of the Chinese food industry, well } \\
\text { known nationally (where is has the dominant market share) and internationally (its products are sold in twenty six countries) for its } \\
\text { White Rabbit brand of milk candy. In July 2007, the Food and Drug Administration of the Philippines announced on two most } \\
\text { influential national television stations that it detected chemical methanol in White Rabbit candies. The product was immediately } \\
\text { removed from the retailers' shelves in the Philippines, and GSL promptly conducted multiple standard quality inspections } \\
\text { internally and externally, with a creditable international inspection agency. The results were released to the media who informed } \\
\text { the consumers that the product did not contain the harmful substance. A further confirmation in a press release came from a high } \\
\text { Chinese official, and was verified by authorities in Hong Kong and Singapore. GSL was successful in defending its reputation and } \\
\text { legitimacy in response to pressures from its key stakeholders, and the product was returned back to retailers' shelves in foreign } \\
\text { markets (Jiang and Shu 2011). }\end{array}$ \\
\hline $\begin{array}{l}\text { Accommodati } \\
\text { ve Strategy }\end{array}$ & $\begin{array}{l}\text { Shanghai Christine Food Ltd Pty, a successful Shanghai-based cake producer with eight manufacturing plans and } 800 \text { direct } \\
\text { national retail outlets, is a good example of this strategy. The Chairman of the company believes that for a food producer and } \\
\text { retailer, the most important corporate social responsibility is to produce and supply healthy and safe food products (Jiang and Yang } \\
\text { 2011). The company has been able to accommodate consumer needs and expectations in an environment where numerous food } \\
\text { companies view profit as their only corporate objective, in the process unlawfully reaping substantial profits through misleading } \\
\text { advertising of poor quality, unsafe products (Wang 1997). }\end{array}$ \\
\hline $\begin{array}{l}\text { Proactive } \\
\text { Strategy }\end{array}$ & $\begin{array}{l}\text { As does Youngor Group, a large Chinese multinational enterprise specialising in fashion designing and manufacturing. Mr Li } \\
\text { Rungang, the Chairman, believes that business is not only a profit-making enterprise, but also an institution that has broader social } \\
\text { responsibilities which need to be integrated into management systems and processes. Top managers internalised these beliefs by } \\
\text { incorporating CSR activities into the group's strategic planning process, ownership structure (e.g., every employee is an owner), } \\
\text { and various practices (e.g., HR and environmental protection practices) (Yang 2007). }\end{array}$ \\
\hline
\end{tabular}


Table 2 Means, Standard Deviations, Correlations, and Scale Reliabilities (Alpha Coefficients) of the Study Variables ${ }^{\text {a }}$

\begin{tabular}{lccccccccc}
\hline Variables & $\mathbf{M}$ & SD & $\mathbf{1}$ & $\mathbf{2}$ & $\mathbf{3}$ & $\mathbf{4}$ & $\mathbf{5}$ & $\mathbf{6}$ & $\mathbf{7}$ \\
\hline 1. Socialist ideology of managers & 6.96 & 1.84 & $(.87)$ & & & & & & \\
2. CSR mindset of managers & 7.87 & 1.23 & $.34^{* *}$ & $(.85)$ & & & & & \\
3. Customer response to CSR & 7.74 & 1.54 & $.30^{* *}$ & $.56^{* *}$ & $(.83)$ & & & & \\
4. Industry competition & 7.08 & 1.23 & $.25^{* *}$ & $.21^{*}$ & $.33^{* *}$ & $(.94)$ & & \\
5. Role of government & 7.92 & 1.75 & $.36^{* *}$ & $.38^{* *}$ & $.57^{* *}$ & $.30^{* *}$ & $(.91)$ & & \\
6. CSR-related managerial incentives & 6.17 & 2.23 & $.44^{* *}$ & $.21^{*}$ & $.24^{* *}$ & .10 & .14 & $(.77)$ & \\
7. CSR strategy of firms & 3.06 & 0.68 & $.28^{* *}$ & $.24^{* *}$ & $.30^{* *}$ & $.22^{* *}$ & $.23^{*}$ & $.25^{* *}$ & $(.98)$ \\
\hline
\end{tabular}

${ }^{a} N=129$. Internal consistency reliabilities appear in parentheses along the diagonal. Corporate social responsibility $=$ CSR.

$* \mathrm{p}<.05 ; * * \mathrm{p}<.01 ; * * * \mathrm{p}<.001$.

Table 3 Results of the Hierarchical Regression Analysis for the Main and Mediation Effects

\begin{tabular}{|c|c|c|c|}
\hline & \multirow{2}{*}{$\begin{array}{c}\text { Mediator } \\
\text { CSR Mindset of Managers }\end{array}$} & \multicolumn{2}{|c|}{ Outcome } \\
\hline & & CSR Strategy of Firms & CSR Strategy of Firms \\
\hline \multicolumn{4}{|l|}{ Main effect } \\
\hline H1a: Socialist ideology of managers & $0.36^{* * *}$ & $0.28^{* *}$ & $0.21^{*}$ \\
\hline H1b: CSR mindset of managers & & $0.24 * *$ & \\
\hline \multicolumn{4}{|l|}{ Mediating effect } \\
\hline H1c: CSR mindset of managers & & & $0.16 \dagger$ \\
\hline \multicolumn{4}{|l|}{ Model fit } \\
\hline $\mathrm{F}$ & $18.53 * * *$ & & $10.46^{* *}$ \\
\hline $\mathrm{R}^{2}$ & 0.13 & & 0.10 \\
\hline Adjusted $\mathrm{R}^{2}$ & 0.12 & & 0.09 \\
\hline$\triangle R^{2}$ in the final step & $0.13 * * *$ & & $0.02 \dagger$ \\
\hline
\end{tabular}

$\dagger \mathrm{p}<.10 ; * \mathrm{p}<.05 ; * * \mathrm{p}<.01 ; * * * \mathrm{p}<.001$. 
Table 4 Results of the Hierarchical Regression Analysis for the Moderation Effects (Dependent Variable: CSR Strategy of Firm)

\begin{tabular}{|c|c|c|c|c|c|c|}
\hline Variables & Model 1 & Model 2 & Model 3 & Model 4 & Model 5 & Model 6 \\
\hline CSR mindset of managers & $0.24 * *$ & 0.08 & 0.09 & 0.03 & 0.10 & 0.08 \\
\hline Customer response to CSR & & 0.20 & 0.13 & 0.13 & 0.15 & $0.20 \dagger$ \\
\hline Industry competition & & 0.10 & 0.15 & 0.12 & $0.16 \dagger$ & $0.20^{*}$ \\
\hline Role of government & & 0.04 & 0.05 & 0.11 & 0.04 & 0.11 \\
\hline H2: CSR mindset of managers $\times$ Customer response to CSR & & $0.16 \dagger$ & & & & $0.18 \dagger$ \\
\hline H3: CSR mindset of managers $\times$ Industry competition & & & -0.13 & & & $-0.28 * *$ \\
\hline H4: CSR mindset of managers $\times$ Role of government & & & & $0.25 * *$ & & $0.31 * * *$ \\
\hline H5: CSR mindset of managers $\times$ CSR-related managerial incentives & & & & & $-0.19 *$ & $-0.27 * * *$ \\
\hline \multicolumn{7}{|l|}{ Model fit } \\
\hline F-value & $7.60 * * *$ & $3.93 * * *$ & $3.77 * * *$ & $4.88^{* * *}$ & $4.28 * * *$ & $5.96^{* * *}$ \\
\hline
\end{tabular}

Note: a. Shown as mediator in the full conceptual framework (Fig. 1)

$\dagger \mathrm{p}<.10 ; * \mathrm{p}<.05 ; * * \mathrm{p}<.01 ; * * * \mathrm{p}<.001$. 
Table 5 Summary of Hypotheses and Results

\begin{tabular}{|c|c|}
\hline Hypotheses & Results \\
\hline $\begin{array}{l}\text { Hypothesis 1a: Socialist ideology will be positively associated with } \\
\text { managers' CSR mindset valuing non-economic responsibilities. }\end{array}$ & Supported \\
\hline $\begin{array}{l}\text { Hypothesis 1b: Managers with a socialist-oriented CSR mindset will } \\
\text { adopt a proactive CSR strategy for their firms. }\end{array}$ & Supported \\
\hline $\begin{array}{l}\text { Hypothesis 1c: The CSR mindset of managers mediates the } \\
\text { relationship between socialist ideology and the choice of CSR strategy. }\end{array}$ & $\begin{array}{l}\text { Supported } \\
\text { (Marginal) }\end{array}$ \\
\hline $\begin{array}{l}\text { Hypothesis 2: Customer responses to the CSR strategy of firms } \\
\text { positively moderate the relationship between the CSR mindset of } \\
\text { managers and the choice of CSR strategy. }\end{array}$ & $\begin{array}{l}\text { Supported } \\
\text { (Marginal) }\end{array}$ \\
\hline $\begin{array}{l}\text { Hypothesis 3: Industry competition negatively moderates the } \\
\text { relationship between the CSR mindset of managers and the choice of } \\
\text { CSR strategy. }\end{array}$ & Supported \\
\hline $\begin{array}{l}\text { Hypothesis 4: The role of government positively moderates the } \\
\text { relationship between the CSR mindset of managers and the choice of } \\
\text { CSR strategy. }\end{array}$ & Supported \\
\hline $\begin{array}{l}\text { Hypothesis 5: CSR-related managerial incentives negatively moderate } \\
\text { the relationship between the CSR mindset of managers and the choice } \\
\text { of CSR strategy. }\end{array}$ & Supported \\
\hline
\end{tabular}




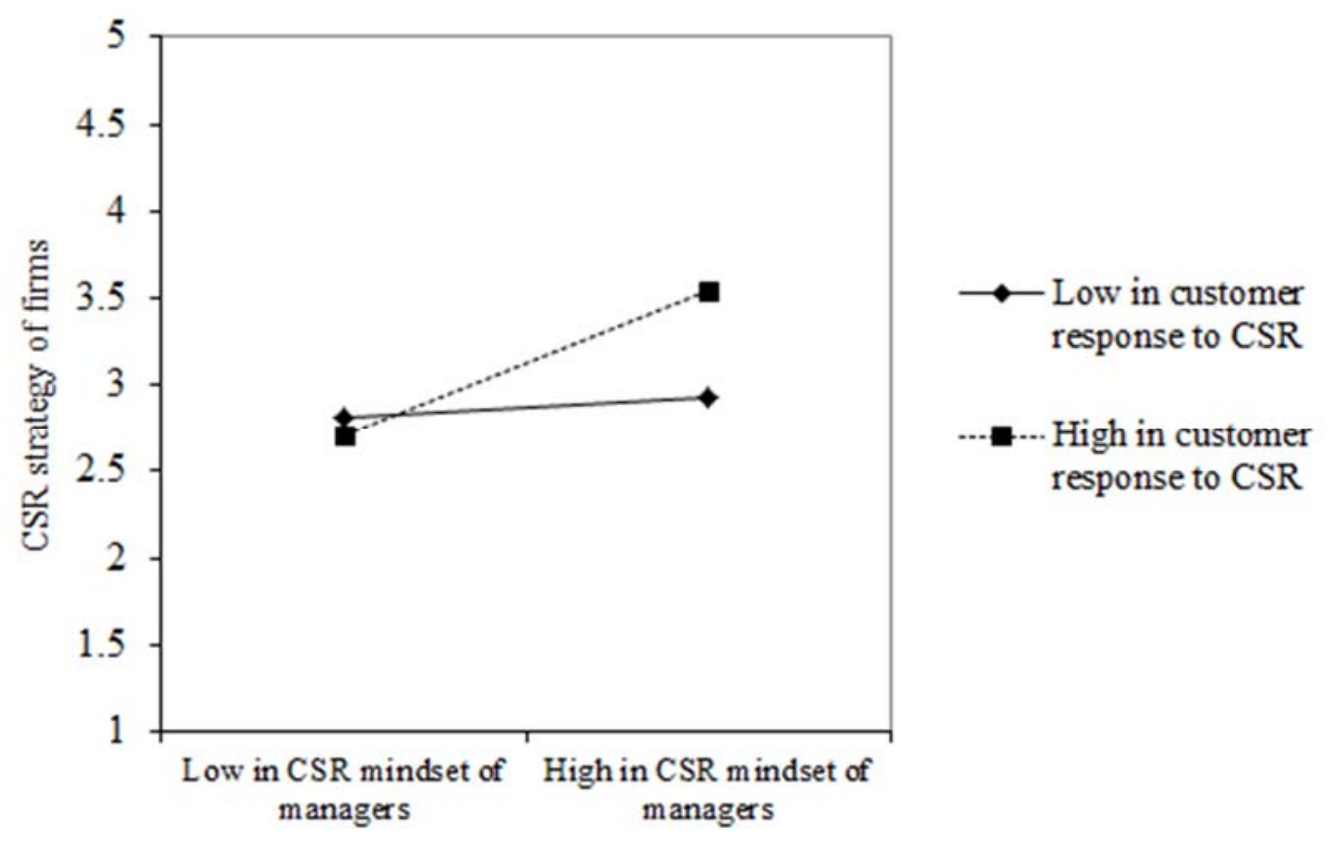

Fig. 3 Interaction of the CSR Mindset of Managers and Customer Responses to CSR in Predicting CSR Strategy

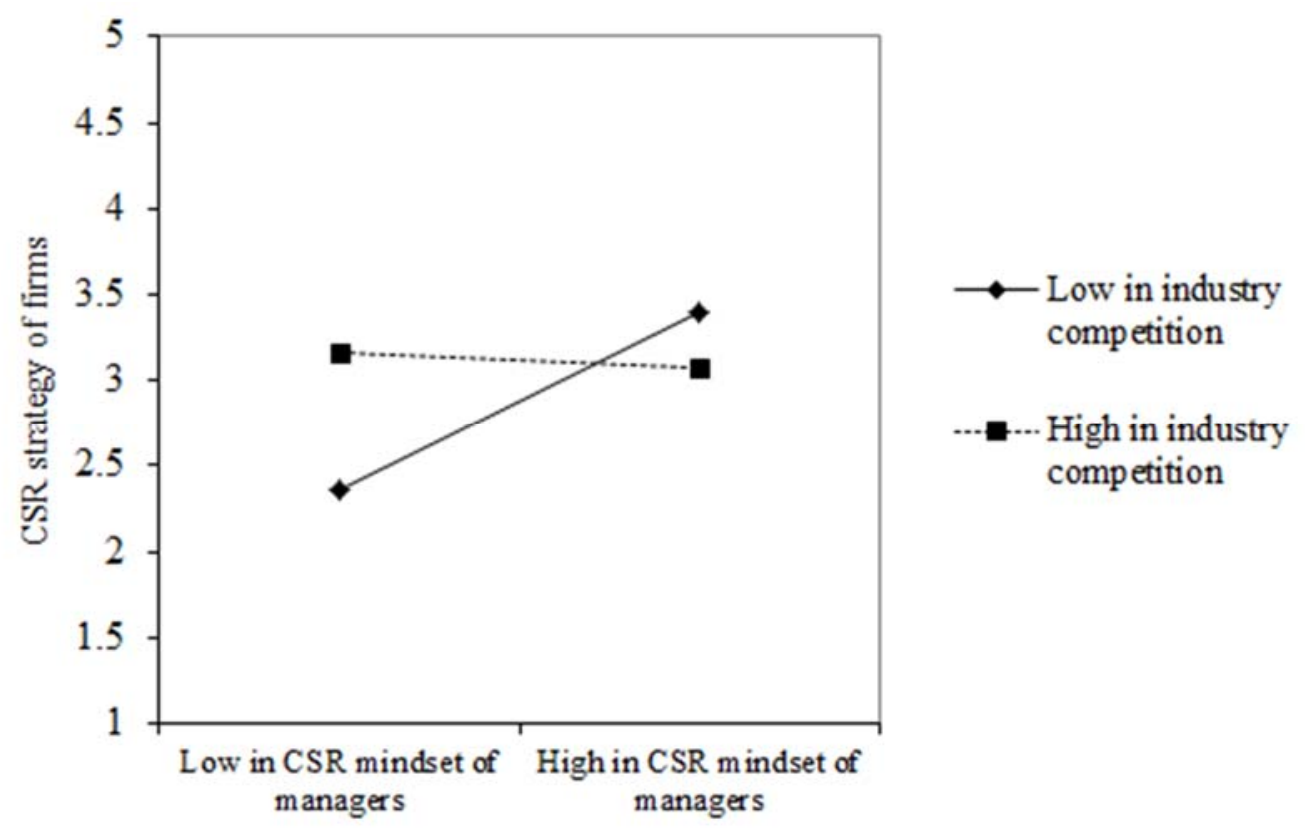

Fig.4 Interaction of the CSR Mindset of Managers and Industry Competition in Predicting CSR Strategy 


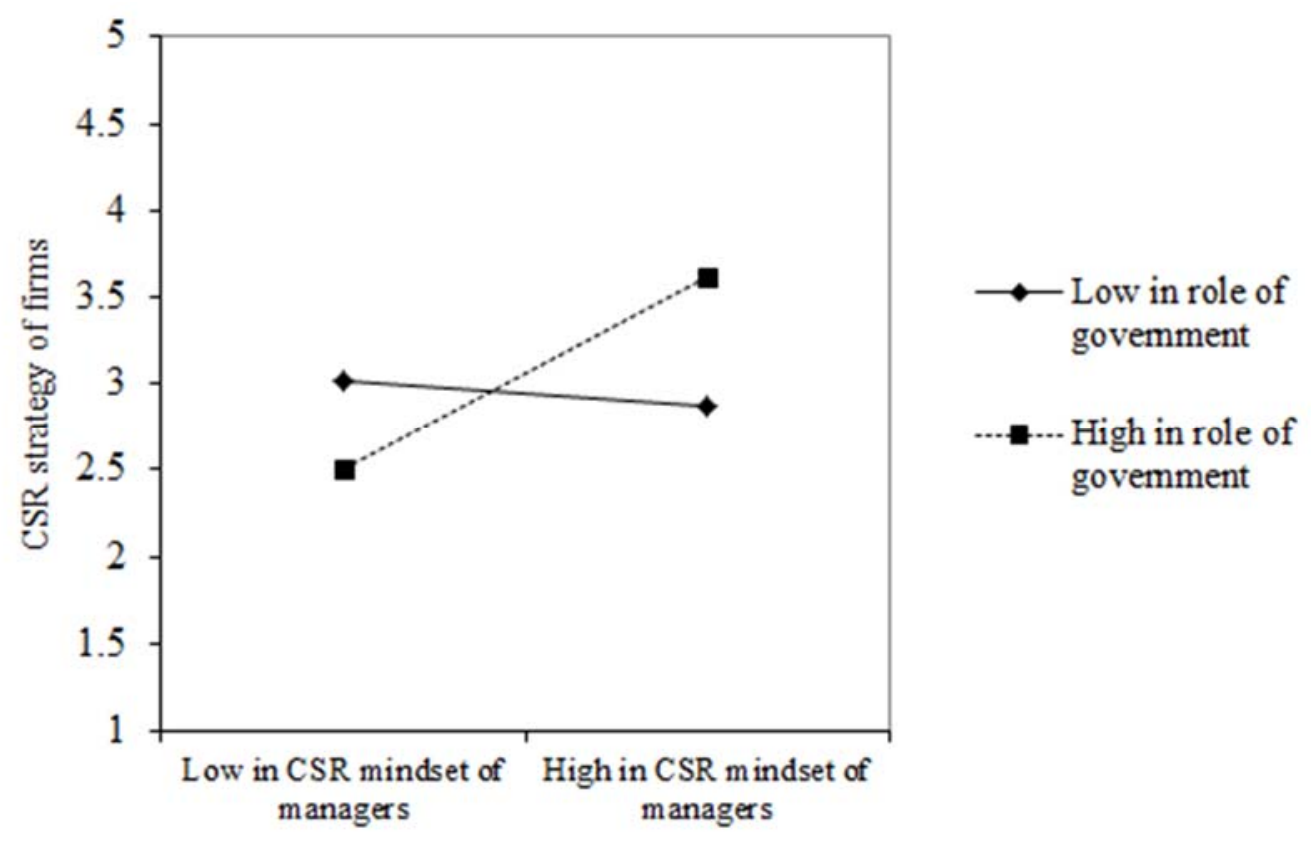

Fig. 5 Interaction of the CSR Mindset of Managers and the Role of Government in Predicting CSR Strategy

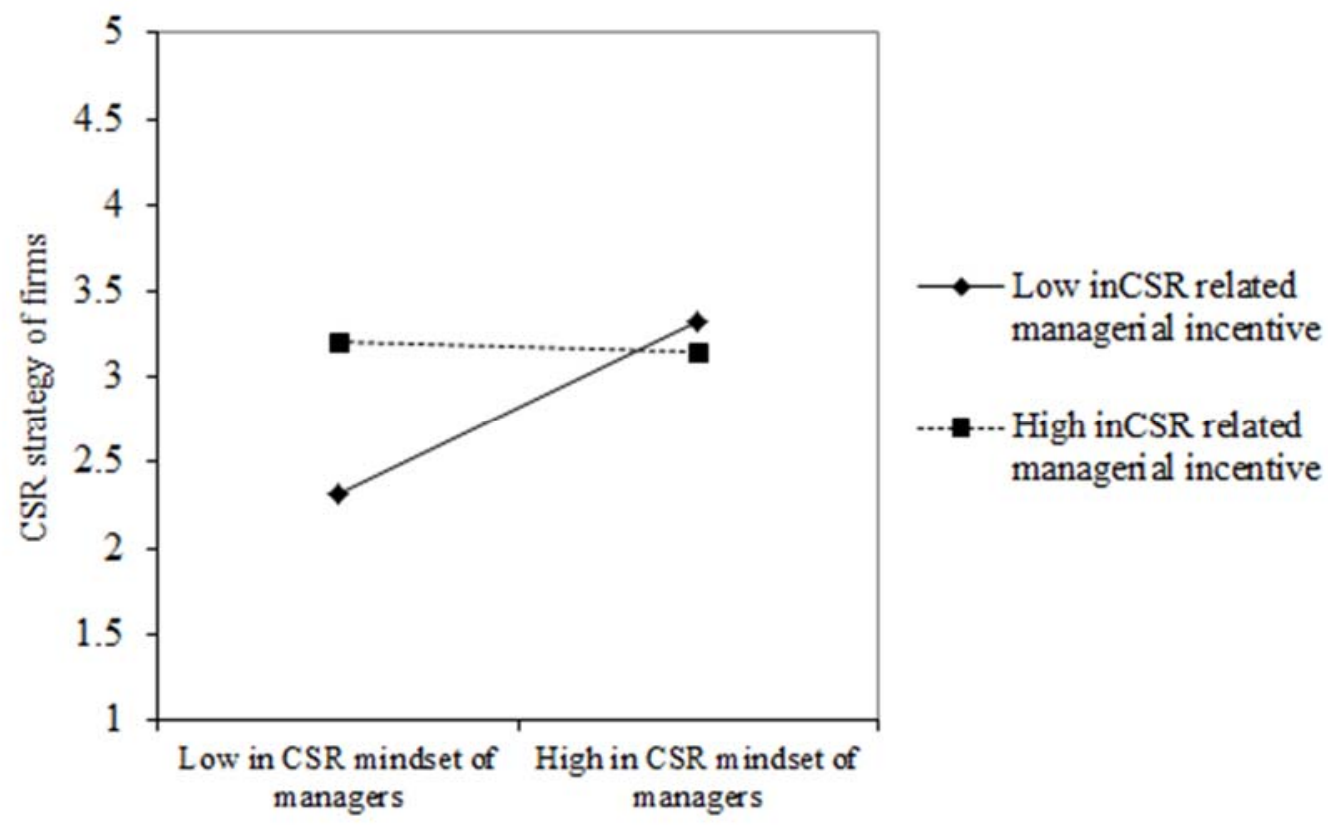

Fig. 6 Interaction of the CSR Mindset of Managers and CSR-Related Managerial Incentives in Predicting CSR Strategy 
Appendix: Variable Measurement

Scale: 10-point Likert scale (' 1 ' being strongly disagree, and '10' being strongly agree)

A1: Socialist Ideology $(\alpha=0.87)$

\begin{tabular}{|c|c|}
\hline Measurement Item/Statement & Source \\
\hline There is a greater danger of corruption and exploitation in a market economy & \multirow{4}{*}{$\begin{array}{l}\text { Jost, Blount, } \\
\text { Pfeffer, and } \\
\text { Hunyady } \\
\text { (2003). }\end{array}$} \\
\hline $\begin{array}{l}\text { A socialist system guarantees an acceptable living standard by providing } \\
\text { economic security to its citizens }\end{array}$ & \\
\hline $\begin{array}{l}\text { It is possible for more people from the lower classes to gain respect and } \\
\text { social mobility through talent and education under socialism }\end{array}$ & \\
\hline $\begin{array}{l}\text { A capitalist market economy leads to a lack of social security and } \\
\text { increased poverty for its citizens }\end{array}$ & \\
\hline $\begin{array}{l}\text { In a socialist society, the economy is run on the principle of the direct } \\
\text { satisfaction of human needs }\end{array}$ & $\begin{array}{l}\text { Schweickart, } \\
\text { et al. (1998) }\end{array}$ \\
\hline Socialism allows for the widespread application of modern technology & \multirow{4}{*}{$\begin{array}{l}\text { Marx and } \\
\text { Engels } \\
(1878 / 2009)\end{array}$} \\
\hline $\begin{array}{l}\text { Socialists create a more just society that would guarantee a certain basic } \\
\text { standard of living }\end{array}$ & \\
\hline $\begin{array}{l}\text { Socialism establishes an economic arrangement that would serve the } \\
\text { interests of society as a whole }\end{array}$ & \\
\hline Market instability is a permanent feature of capitalist economy & \\
\hline $\begin{array}{l}\text { Capitalism is responsible for imperialist, colonialist and counter- } \\
\text { revolutionary wars, repressions of workers and trade unionists, genocides } \\
\text { and massacres }\end{array}$ & Lenin (1917). \\
\hline
\end{tabular}

A2: CSR Mindset $(\alpha=0.85)$

\begin{tabular}{|c|c|}
\hline Measurement Item/Statement & Source \\
\hline $\begin{array}{l}\text { Responsible corporate behaviour can be in the best economic interest of the } \\
\text { stockholder }\end{array}$ & \multirow{11}{*}{$\begin{array}{l}\text { Davis (1973) } \\
\text { Ford and } \\
\text { McLaughlin } \\
\text { (1984). }\end{array}$} \\
\hline $\begin{array}{l}\text { Efficient production of goods and services is no longer the only thing society } \\
\text { expects from business }\end{array}$ & \\
\hline $\begin{array}{l}\text { Long-run success of business depends on its ability to understand that it is } \\
\text { part of a larger society and to behave accordingly }\end{array}$ & \\
\hline $\begin{array}{l}\text { Involvement by business in improving its community's quality of life will } \\
\text { also improve long run profitability }\end{array}$ & \\
\hline $\begin{array}{l}\text { A business that wishes to capture a favourable public image will have to } \\
\text { show that it is socially responsible }\end{array}$ & \\
\hline $\begin{array}{l}\text { Social problems such as pollution control sometimes can be solved in ways } \\
\text { that produce profits from the problem solution }\end{array}$ & \\
\hline $\begin{array}{l}\text { If business is more socially responsible, it will discourage additional } \\
\text { regulation of the economic system by government }\end{array}$ & \\
\hline $\begin{array}{l}\text { If business delays dealing with social problems now, it may find itself } \\
\text { increasingly occupied with bigger social issues later such that it will be } \\
\text { unable to perform its primary business tasks }\end{array}$ & \\
\hline $\begin{array}{l}\text { The idea of social responsibility is needed to balance corporate power and } \\
\text { discourage irresponsible behaviour }\end{array}$ & \\
\hline $\begin{array}{l}\text { Other social institutions have failed in solving social problems so business } \\
\text { should try }\end{array}$ & \\
\hline $\begin{array}{l}\text { Since businesses have such a substantial amount of society's managerial and } \\
\text { financial resources, they should be expected to solve social problems }\end{array}$ & \\
\hline
\end{tabular}


A3: Customer Response to CSR $(\alpha=0.83)$

\begin{tabular}{|c|c|}
\hline Measurement Item/Statement & Source \\
\hline $\begin{array}{l}\text { Customers have a strong sense of connection with my company through the } \\
\text { products and services that it delivers }\end{array}$ & \multirow{5}{*}{$\begin{array}{l}\text { Luo and } \\
\text { Bhattacharya } \\
\text { (2006); } \\
\text { Maignan } \\
\text { (2001). }\end{array}$} \\
\hline Customers value my company's corporate social responsibility record & \\
\hline $\begin{array}{l}\text { Customers have influence on the corporate social responsibility initiatives in } \\
\text { my company }\end{array}$ & \\
\hline $\begin{array}{l}\text { Customers are willing to buy my organisation's product/service because of } \\
\text { its reputation as a socially responsible organisation }\end{array}$ & \\
\hline There is a generally high level of ethical consumerism & \\
\hline
\end{tabular}

A4: Industry Competition $(\alpha=0.94)$

\begin{tabular}{|l|l|}
\hline Measurement Item/Statement & Source \\
\hline Competition in our industry is 'cutthroat" & Jaworski and \\
\cline { 1 - 1 } There are many promotion 'wars' in our industry & \\
\hline Anything that one competitor can offer, others can match readily & \\
\cline { 1 - 1 } $\begin{array}{l}\text { We are witnessing demand for our products and services from customers } \\
\text { who never bought them before }\end{array}$ & \\
\cline { 1 - 1 } $\begin{array}{l}\text { New customers tend to have product-related needs that are different from } \\
\text { those of our existing customers }\end{array}$ & \\
\cline { 1 - 1 } We cater to many of the same customers that we used to in the past & \\
\hline
\end{tabular}

A5:Role of Government $(\alpha=0.91)$

\begin{tabular}{|l|l|}
\hline Measurement Item/Statement & Source \\
\hline Government holds corporations accountable for CSR behaviour & $\begin{array}{l}\text { Albareda, Ysa, } \\
\text { and Lozano } \\
\text { (2005). }\end{array}$ \\
\cline { 1 - 1 } $\begin{array}{l}\text { Government directly encourages (gives priority for awarding contracts) } \\
\text { firms with good CSR records }\end{array}$ & \\
\cline { 1 - 1 } Government recognises and promotes good CSR behaviour and practice & \\
\cline { 1 - 1 } Government provides tax benefits for good CSR behaviour & \\
\cline { 1 - 1 } $\begin{array}{l}\text { Government provides administrative support to firms for good CSR } \\
\text { behaviour }\end{array}$ & \\
\cline { 1 - 1 } Government penalises firms' unethical behaviour & \\
\cline { 1 - 1 } Government strongly enforces regulations & \\
\hline
\end{tabular}

A6: Managerial Incentives $(\alpha=0.77)$

\begin{tabular}{|c|c|}
\hline Measurement Item/Statement & Source \\
\hline $\begin{array}{l}\text { An individual manager's performance is mainly measured by my company's } \\
\text { vision and business goal }\end{array}$ & \multirow{4}{*}{$\begin{array}{l}\text { Adapted from } \\
\text { Berrone and } \\
\text { Gomez-Meija } \\
\text { (2009); } \\
\text { Deckop et al. } \\
\text { (2006); } \\
\text { McGuire et } \\
\text { al., (2003). }\end{array}$} \\
\hline $\begin{array}{l}\text { An individual manager's compensation package depends on his/her } \\
\text { performance on the CSR metric }\end{array}$ & \\
\hline $\begin{array}{l}\text { How well an individual manager performs on CSR is as important as how } \\
\text { well the manager performs on financial metrics in assessing the manager's } \\
\text { performance }\end{array}$ & \\
\hline $\begin{array}{l}\text { How well an individual manager performs on CSR is more important than } \\
\text { how well the manager performs on financial metrics in assessing the } \\
\text { manager's performance }\end{array}$ & \\
\hline
\end{tabular}

